Article

\title{
Developing a Library of Mannose-Based Mono- and Disaccharides: A General Chemoenzymatic Approach to Monohydroxylated Building Blocks
}

\author{
Lisa Tanzi ${ }^{1,2,+}$, Marina Simona Robescu ${ }^{1,+} \oplus$, Sara Marzatico ${ }^{1}$, Teresa Recca ${ }^{3}$, \\ Yongmin Zhang $^{2}{ }^{(D)}$, Marco Terreni ${ }^{1}$ and Teodora Bavaro ${ }^{1, *(D)}$ \\ 1 Department of Drug Sciences, University of Pavia, viale Taramelli 12, I-27100 Pavia, Italy; \\ lisa.tanzi01@universitadipavia.it (L.T.); marinasimona.robescu@unipv.it (M.S.R.); \\ sara.marzatico01@universitadipavia.it (S.M.); marco.terreni@unipv.it (M.T.) \\ 2 Institut Parisien de Chimie Moléculaire, Sorbonne Université, CNRS, UMR 8232, 4 Place Jussieu, \\ 75005 Paris, France; yongmin.zhang@upmc.fr \\ 3 Centro Grandi Strumenti, University of Pavia, via Bassi 21, I-27100 Pavia, Italy; teresa.recca@unipv.it \\ * Correspondence: teodora.bavaro@unipv.it; Tel.: +39-0382-987-889 \\ + These authors contributed equally to this work.
}

Academic Editor: Giangiacomo Torri

Received: 15 November 2020; Accepted: 4 December 2020; Published: 7 December 2020

\begin{abstract}
Regioselective deprotection of acetylated mannose-based mono- and disaccharides differently functionalized in anomeric position was achieved by enzymatic hydrolysis. Candida rugosa lipase (CRL) and Bacillus pumilus acetyl xylan esterase (AXE) were immobilized on octyl-Sepharose and glyoxyl-agarose, respectively. The regioselectivity of the biocatalysts was affected by the sugar structure and functionalization in anomeric position. Generally, CRL was able to catalyze regioselective deprotection of acetylated monosaccharides in $\mathrm{C} 6$ position. When acetylated disaccharides were used as substrates, AXE exhibited a marked preference for the $\mathrm{C} 2$, or $\mathrm{C} 6$ position when $\mathrm{C} 2$ was involved in the glycosidic bond. By selecting the best enzyme for each substrate in terms of activity and regioselectivity, we prepared a small library of differently monohydroxylated building blocks that could be used as intermediates for the synthesis of mannosylated glycoconjugate vaccines targeting mannose receptors of antigen presenting cells.
\end{abstract}

Keywords: acetyl xylan esterase; Candida rugosa lipase; enzyme immobilization; enzymatic hydrolysis; monosaccharides; disaccharides; mannose-based oligosaccharides

\section{Introduction}

Oligosaccharides are involved in the modulation of biomolecules properties and in the communication between cells; thus, they play important roles in a variety of physiological and pathological processes, such as cell growth and proliferation, angiogenesis, protein folding and degradation, cell-cell communication, cell-pathogen interactions and immune response [1]. In human cells, oligosaccharides often occur as glycoconjugates attached to other macromolecules, such as lipids (glycolipids) and proteins (glycoproteins) [2]. Glycoconjugates can promote the immune response through the production of antibodies against a specific target; therefore, their use as vaccines has been proven to be a successful strategy to prevent infectious diseases [3].

Mannose-based glycoconjugates were investigated for improving antigens up-take mediated via the mannose receptor (MR) of human antigen presenting cells (APCs). MR belongs to C-type lectin receptor family and it has numerous functions, including the recognition of glycans present on microorganisms surface and the consequent antigen internalization by phagocytosis and presentation [4]. The discovery 
of MR role in antigen up-take stimulated the research towards the development of mannosylated antigens with the aim to design vaccines with improved immunogenicity by targeting MR [5].

Several studies regarding natural high-mannosylated glycoprotein120 (GP120) fragments as potential human deficiency virus (HIV) vaccine were previously reported [6,7]. In HIV, high-mannose glycans with $\alpha-(1 \rightarrow 6)$ and $\alpha$ - $(1 \rightarrow 2)$ motifs are included in the important envelope glycoprotein GP120, involved in the mediation of the infection process by interacting with MR exposed on APC cells surface. Unfortunately, this approach resulted poorly efficient for the development of an effective HIV vaccine candidate, but it suggested the idea that mannosylation with natural polymannan or its analogues, being well-recognized by MR of APC, represents a possible strategy to improve the antigenic activity of peptides or proteins. Similarly, different synthetic $\alpha-(1 \rightarrow 6)$ polymannan, mimicking Mycobacterium tuberculosis polysaccharides, were synthesized and characterized showing good binding affinity for lectins [8].

However, the structural diversity and complexity of natural oligosaccharides, including polymannan, make their production from natural sources and characterization extremely complicated. Thus, chemical and/or enzymatic synthesis can represent a valid alternative for the production of structure-defined oligosaccharides analogues in high purity, by exploiting efficient and scalable protocols [9]. Automatized methods either chemical or enzymatic have been developed over the years for the synthesis of oligosaccharides [10,11], including an $\alpha-(1 \rightarrow 6)-30$ mer-mannoside [12]. However, the preparation of sugar acceptor building blocks bearing only one free hydroxyl group in the desired position represents the main bottleneck in the synthesis of oligosaccharides. Usually, the chemical synthesis of monodeprotected monosaccharides and disaccharides is performed through orthogonal multistep processes, which frequently result in low yields [13,14].

The use of enzyme-catalyzed reactions provides, instead, a more straightforward route: hydrolases have been successfully employed as catalysts in the regioselective deprotection of peracetylated mono- [15-18] and disaccharides [19-21] under mild reaction conditions. Hence, lipases (EC 3.1.1.3) and esterases (EC 3.1.1.x) represent valuable tools for a simple and efficient chemoenzymatic approach in the preparation of sugar building blocks involving the use of acetyl moiety as the only protecting group [21,22]. In particular, the availability of synthetic tools for the production of acetylated mannose building blocks with only one free hydroxyl group and different reactive groups in anomeric position would facilitate the preparation of polymannan analogues with $\alpha-(1 \rightarrow 6)$ and $\alpha-(1 \rightarrow 2)$ motifs and the subsequent biological evaluation of their corresponding glycoconjugates derivatives.

In this context, the use of immobilized hydrolases is highly sought since peracetylated sugars, especially disaccharides, are scarcely soluble in aqueous medium; thus, the use of organic co-solvents is required. Stabilization of enzymes via immobilization techniques is a valuable strategy to enhance the stability of biocatalysts in the presence of organic co-solvents and their easy recovery from reaction mixture and re-use [23]. The immobilization of lipases on hydrophobic supports, by means of interfacial adsorption (e.g., on octyl-Sepharose or octadecyl-Sepabeads), is a well-established methodology for obtaining highly active biocatalysts [24] with good stability in the presence of organic co-solvents [25].

Conversely, this simple methodology is not suited for esterases due to their different 3D-architecture and kinetics [26,27]. However, the esterase fraction from the crude extract of Aspergillus niger lipase (ANL) and acetyl xylan esterase from Bacillus pumilus (AXE) were successfully immobilized by covalent interaction on acrylic carriers and employed for the deprotection of acetylated mono- and disaccharides [15,19,21].

In the present work we report on a comparison between immobilized Candida rugosa lipase (CRL) and acetyl xylan esterase from Bacillus pumilus (AXE) in the synthesis of monohydroxylated sugar building blocks. A new immobilization protocol based on agarose carrier was developed for AXE to obtain a robust biocatalyst under a wide range of experimental conditions. An extensive screening of acetylated mannose-based mono- and disaccharides differently functionalized in $\mathrm{C} 1$ position provided a library of monodeprotected intermediates useful for the synthesis of mannosylated glycoproducts. 


\section{Results and Discussion}

\subsection{Immobilization of Acetyl Xylan Esterase from Bacillus Pumilus and Stability Studies}

Considering that the acetylated monosaccharides and disaccharides are not completely soluble in buffer, we evaluated the stability of soluble acetyl xylan esterase from Bacillus pumilus (AXE) in different types of co-solvents present in the reaction mixture at different percentages $v / v$ (Figure 1A). Soluble AXE was quite stable in all the reaction mixtures tested. After $48 \mathrm{~h}$ of incubation in $90 \%$ ethanol, the enzyme maintained a residual activity of $90 \%$. However, in the presence of acetonitrile and tert-butanol, the biocatalyst showed lower stability after $48 \mathrm{~h}$ incubation (Figure $1 \mathrm{~A}$ ). Thus, in order to obtain a robust biocatalyst, different immobilization carriers were evaluated.

A

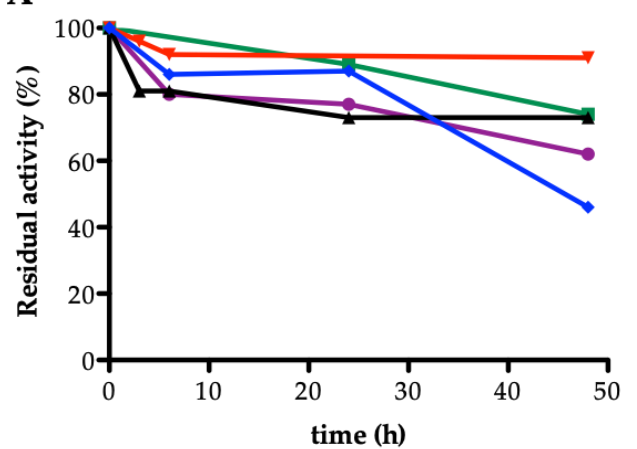

B

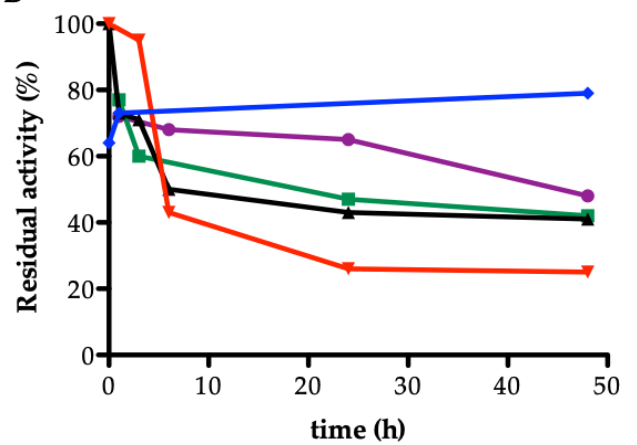

Figure 1. Stability of soluble acetyl xylan esterase from Bacillus pumilus (AXE) (A) and immobilized AXE on acrylic epoxy resin (B) in different organic co-solvents at different percentages $v / v: 15 \%$ acetonitrile (purple circles), 30\% acetonitrile (green squares), 50\% acetonitrile (black triangles), 90\% ethanol (red triangles), 90\% tert-butanol (blue rhombus). The measurements were performed in duplicate.

Immobilized AXE on acrylic epoxy resin was already successfully employed for the selective deprotection of peracetylated lactose and $\mathrm{N}$-acetyl glucosamine derivatives [15,21]; however, a low stability profile of the biocatalyst during the reaction course was observed. As reported in Figure 1B, the residual activity of immobilized AXE on acrylic epoxy resin after $48 \mathrm{~h}$ incubation is lower than $60 \%$ in all conditions tested, except $90 \%$ tert-butanol, in which the enzyme maintained between $70 \%-80 \%$ residual activity.

Thus, a new immobilization protocol was set-up for AXE considering its multimeric three-dimensional structure. In fact, AXE has a complex hexameric quaternary structure formed by a dimer of trimers showing a "doughnut-shaped" assembly with the six active centers disposed towards a central pore $[28,29]$. When working with multimeric enzymes, the immobilization technique must be able to bind all the subunits in order to keep the quaternary structure of the enzyme unmodified (or poorly modified) under the selected experimental conditions. The potential dissociation into the single constitutive monomers can cause the loss of activity. This dissociative process is usually enhanced by extreme $\mathrm{pH}$ values, high temperature, and the presence of organic co-solvents, conditions often necessary to ensure the solubility of poorly water soluble substrates [30].

We decided to use glyoxyl-agarose (GLX-AG), a hydrophilic carrier activated with aldehyde functional groups, for AXE immobilization. GLX-AG has a wide hydrophilic superficial area and pores of such dimensions to harbor proteins in a wide range of molecular weights. In addition, the presence of several hydroxyl groups on its surface, that can be easily activated, allows for the formation of a high number of bonds between the enzyme and the carrier resulting in a three-dimensional network of covalent multipoint interactions with consequent stabilization effects [31]. Successful immobilization procedures for multimeric proteins stabilization based on this carrier have been widely described [32,33].

Different parameters were screened, such as temperature, time, and protein loading in order to optimize AXE immobilization on GLX-AG. As shown in Table 1, when using a loading of $150 \mathrm{mg} / \mathrm{g}$ 
and $25^{\circ} \mathrm{C}, \mathrm{AXE}$ immobilized on acrylic epoxy resin showed higher immobilization yields in terms of quantity of immobilized protein (39\%) and activity (38\%) when compared to GLX-AG derivative ( $28 \%$ of protein and $33 \%$ of activity immobilized); however, the activity of this derivative was almost four-fold lower (107 U/g vs. $383 \mathrm{U} / \mathrm{g}$ ). Thus, it seems that the hydrophobic microenvironment of acrylic surface around the enzyme negatively influences its activity, while the hydrophilic nature of agarose seems to be preferred. Moreover, the multipoint interaction of the enzyme with the three-dimensional network of agarose fibers may prevent subunits dissociation maintaining the correct quaternary structure of the protein and, thus, its activity. In addition, the short time incubation needed for GLX-AG immobilization protocol compared to acrylic resin immobilization ( $3 \mathrm{~h}$ instead of $24 \mathrm{~h}$ ) can explain the better performances of GLX-AG biocatalyst. We further tried to optimize GLX-AG immobilization procedure by lowering the temperature to $4{ }^{\circ} \mathrm{C}$ in order to prevent subunits dissociation during the immobilization process. However, as shown in Table 1, we were able to slightly increase the immobilization yield in terms of activity (48\%), but the final activity expressed by the derivative was lower compared to the immobilization procedure performed at $25^{\circ} \mathrm{C}(283 \mathrm{U} / \mathrm{g}$ vs. $383 \mathrm{U} / \mathrm{g})$. The longer incubation time ( $18 \mathrm{~h}$ instead of $3 \mathrm{~h}$ ) at pH 10 may negatively influence the stability of the enzyme. Finally, as in all the conditions tested we have observed low protein binding to the supports $(26 \%-39 \%$ of the total protein used), we decided to decrease the immobilization loading from $150 \mathrm{mg} / \mathrm{g}$ to $50 \mathrm{mg} / \mathrm{g}$. In these conditions, we obtained a two-fold increase in the \% of immobilized protein (61\% vs. $28 \%)$ and an improvement of immobilized activity (43\% vs. 33\%). Thus, the best immobilization conditions on GLX-AG were $25^{\circ} \mathrm{C}, 3 \mathrm{~h}$ using $50 \mathrm{mg} / \mathrm{g}$ of protein. This biocatalyst was further used in all the experiments reported in this paper.

Table 1. Immobilization screening.

\begin{tabular}{|c|c|c|c|c|c|c|}
\hline $\begin{array}{c}\text { Immobilization } \\
\text { Carrier }\end{array}$ & $\begin{array}{c}\text { Temperature } \\
\left({ }^{\circ} \mathrm{C}\right)\end{array}$ & $\begin{array}{l}\text { Time } \\
\text { (h) }\end{array}$ & $\begin{array}{c}\text { Loading }^{b} \\
(\mathrm{mg} / \mathrm{g})\end{array}$ & $\begin{array}{l}\text { Immobilized } \\
\text { Protein }(\%)\end{array}$ & $\begin{array}{l}\text { Immobilized } \\
\text { Activity (\%) }\end{array}$ & $\begin{array}{l}\text { Activity } \\
\text { (U/g) }\end{array}$ \\
\hline Acrylic resin ${ }^{a}$ & 25 & 24 & 150 & 39 & 38 & 107 \\
\hline GLX-AG & 4 & 18 & 150 & 26 & 48 & 283 \\
\hline GLX-AG & 25 & 3 & 150 & 28 & 33 & 383 \\
\hline GLX-AG & 25 & 3 & 50 & 61 & 43 & 392 \\
\hline
\end{tabular}

a Sepabeads EC-EP/M from Resindion. ${ }^{\mathrm{b}}$ Quantity of protein used in the immobilization process per gram of carrier.

The stability of AXE immobilized on GLX-AG was evaluated in 50\% acetonitrile and phosphate buffer (100 mM; pH 7.0), and it was compared to that of the derivative immobilized on acrylic resin. As shown in Figure 2, AXE immobilized on GLX-AG showed higher stability compared to the acrylic resin derivative: GLX-AG derivative maintained $80 \%$ of its activity after $48 \mathrm{~h}$ of incubation, while the acrylic resin derivative lost almost $50 \%$ of its activity, in the same conditions.

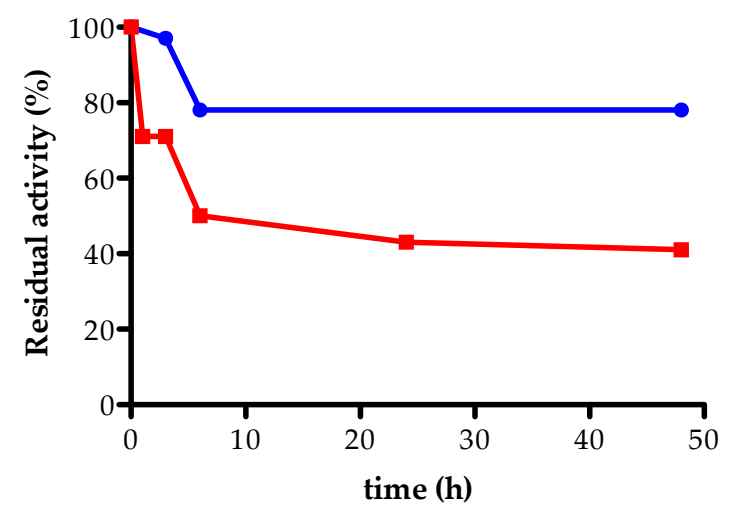

Figure 2. Stability of immobilized AXE on acrylic epoxy resin (red squares) and on glyoxyl-agarose (GLX-AG) (blue circles) in 50\% acetonitrile. The measurements have been performed in duplicate. 


\subsection{Enzymatic Hydrolysis of Peracetylated Monosaccharides (1-8)}

The enzymatic regioselective hydrolysis of different peracetylated D-mannopyranoses (1-7) and one glucosamine derivative (8) (Scheme 1) was studied by using Candida rugosa lipase (CRL) immobilized on octyl-Sepharose ${ }^{\circledR}$ (OC-AG) and acetyl xylan esterase from Bacillus pumilus (AXE) immobilized on glyoxyl-agarose (GLX-AG) in order to screen the regioselectivity of the two biocatalysts. The results are shown in Table 2. CRL was highly selective hydrolyzing preferably the primary position (C6) for compounds 1, 3, 4, 5, 6, and 7 forming, respectively, 1a [17], 3a [34], 4a, 5a, 6a, and 7a [34] with good yields (50\%-81\%). Compound 2 was deacetylated by CRL simultaneously in position C6 and C2, giving access to $\mathbf{2 a}(50 \%)$ and $\mathbf{2 b}(40 \%)$, both useful building blocks for further oligosaccharides synthesis [17]. Compared to CRL, AXE seemed less specific for the same compounds, showing the same regioselectivity as CRL but lower yields $(24 \%-50 \%)$ due to the formation of undesired by-products.

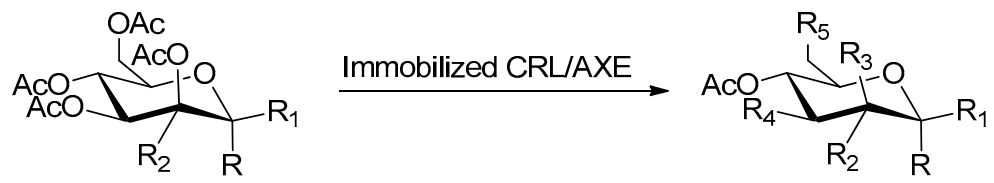

$1 \mathrm{R}=\mathrm{OAc}, \mathrm{R}_{1}=\mathrm{H}, \mathrm{R}_{2}=\mathrm{H}$

$2 \mathrm{R}=\mathrm{SCH}_{2} \mathrm{CN}, \mathrm{R}_{1}=\mathrm{H}, \mathrm{R}_{2}=\mathrm{H}$

$3 \mathrm{R}=\mathrm{STol}, \mathrm{R}_{1}=\mathrm{H}, \mathrm{R}_{2}=\mathrm{H}$

$4 \mathrm{R}=\mathrm{SCH}_{2} \mathrm{CH}_{3}, \mathrm{R}_{1}=\mathrm{H}, \mathrm{R}_{2}=\mathrm{H}$

$5 \mathrm{R}=\mathrm{OCH}_{2} \mathrm{CCH}, \mathrm{R}_{1}=\mathrm{H}, \mathrm{R}_{2}=\mathrm{H}$

$6 \mathrm{R}=\mathrm{OCH}_{2} \mathrm{CH}=\mathrm{CH}_{2}, \mathrm{R}_{1}=\mathrm{H}, \mathrm{R}_{2}=\mathrm{H}$

$7 \mathrm{R}=\mathrm{O}\left(\mathrm{CH}_{2}\right)_{3} \mathrm{~N}_{3}, \mathrm{R}_{1}=\mathrm{H}, \mathrm{R}_{2}=\mathrm{H}$

$8 \mathrm{R}=\mathrm{H}, \mathrm{R}_{1}=\mathrm{SCH}_{2} \mathrm{CN}, \mathrm{R}_{2}=\mathrm{NHAC}$ 1a $\mathrm{R}=\mathrm{OAc}, \mathrm{R}_{1}=\mathrm{H}, \mathrm{R}_{2}=\mathrm{H}, \mathrm{R}_{3}=\mathrm{OAc}, \mathrm{R}_{4}=\mathrm{OAc}, \mathrm{R}_{5}=\mathrm{OH}$ 1b $\mathrm{R}=\mathrm{OH}, \mathrm{R}_{1}=\mathrm{H}, \mathrm{R}_{2}=\mathrm{H}, \mathrm{R}_{3}=\mathrm{OAc}, \mathrm{R}_{4}=\mathrm{OAc}, \mathrm{R}_{5}=\mathrm{OAc}$ 2a R= SCH $\mathrm{CHN}_{2}, \mathrm{R}_{1}=\mathrm{H}, \mathrm{R}_{2}=\mathrm{H}, \mathrm{R}_{3}=\mathrm{OAc}, \mathrm{R}_{4}=\mathrm{OAc}, \mathrm{R}_{5}=\mathrm{OH}$ 2b R= SCH $\mathrm{SN}_{2}, \mathrm{R}_{1}=\mathrm{H}, \mathrm{R}_{2}=\mathrm{H}, \mathrm{R}_{3}=\mathrm{OH}, \mathrm{R}_{4}=\mathrm{OAc}, \mathrm{R}_{5}=\mathrm{OAc}$ 3a R= STol, $\mathrm{R}_{1}=\mathrm{H}, \mathrm{R}_{2}=\mathrm{H}, \mathrm{R}_{3}=\mathrm{OAc}, \mathrm{R}_{4}=\mathrm{OAc}, \mathrm{R}_{5}=\mathrm{OH}$ 4a $\mathrm{R}=\mathrm{SCH}_{2} \mathrm{CH}_{3}, \mathrm{R}_{1}=\mathrm{H}, \mathrm{R}_{2}=\mathrm{H}, \mathrm{R}_{3}=\mathrm{OAc}, \mathrm{R}_{4}=\mathrm{OAc}, \mathrm{R}_{5}=\mathrm{OH}$ 5a R= OCH $\mathrm{OCCH}_{2} \mathrm{R}_{1}=\mathrm{H}, \mathrm{R}_{2}=\mathrm{H}, \mathrm{R}_{3}=\mathrm{OAc}, \mathrm{R}_{4}=\mathrm{OAc}, \mathrm{R}_{5}=\mathrm{OH}$ 5b R= $\mathrm{OCH}_{2} \mathrm{CCH}, \mathrm{R}_{1}=\mathrm{H}, \mathrm{R}_{2}=\mathrm{H}, \mathrm{R}_{3}=\mathrm{OH}, \mathrm{R}_{4}=\mathrm{OAc}, \mathrm{R}_{5}=\mathrm{OAc}$ 6a R= $\mathrm{OCH}_{2} \mathrm{CH}=\mathrm{CH}_{2}, \mathrm{R}_{1}=\mathrm{H}, \mathrm{R}_{2}=\mathrm{H}, \mathrm{R}_{3}=\mathrm{OAc}, \mathrm{R}_{4}=\mathrm{OAc}, \mathrm{R}_{5}=\mathrm{OH}$ 7a R= $\left(\mathrm{CH}_{2}\right)_{3} \mathrm{~N}_{3}, \mathrm{R}_{1}=\mathrm{H}, \mathrm{R}_{2}=\mathrm{H}, \mathrm{R}_{3}=\mathrm{OAc}, \mathrm{R}_{4}=\mathrm{OAc}, \mathrm{R}_{5}=\mathrm{OH}$ 8a R= H, R $\mathrm{R}_{1}=\mathrm{SCH}_{2} \mathrm{CN}, \mathrm{R}_{2}=\mathrm{NHAc}, \mathrm{R}_{3}=\mathrm{H}, \mathrm{R}_{4}=\mathrm{OAc}, \mathrm{R}_{5}=\mathrm{OH}$

Scheme 1. Regioselective enzymatic hydrolysis of peracetylated mannopyranosydes 1-7 and $N$-acetyl glucosamine (8) derivatives.

Table 2. Regioselective enzymatic hydrolysis of monosaccharides.

\begin{tabular}{|c|c|c|c|c|c|c|}
\hline \multirow{4}{*}{$\begin{array}{c}\text { Substrate } \\
1\end{array}$} & \multirow{4}{*}{$\begin{array}{c}\text { Enzyme } \\
\text { CRL } \\
\text { AXE }\end{array}$} & \multirow{3}{*}{$\begin{array}{c}\text { Time (h) } \\
21\end{array}$} & \multirow{4}{*}{$\begin{array}{c}\text { Position } \\
6 \mathrm{OH} \\
1 \mathrm{OH} \\
1 \mathrm{OH}\end{array}$} & \multicolumn{2}{|c|}{ Product (Yield) } & \multirow{3}{*}{$\begin{array}{c}\text { By-Products } \\
(10 \%)\end{array}$} \\
\hline & & & & $1 \mathrm{a}$ & $(77 \%)$ & \\
\hline & & & & $1 b$ & $(13 \%)$ & \\
\hline & & 24 & & $1 b$ & $(50 \%)$ & - \\
\hline \multirow{3}{*}{2} & CRI & 20 & $6 \mathrm{OH}$ & $2 a$ & $(50 \%)$ & (10\%) \\
\hline & CRL & 20 & $2 \mathrm{OH}$ & $2 b$ & $(40 \%)$ & $(10 \%)$ \\
\hline & AXE & 72 & $6 \mathrm{OH}$ & $2 a$ & $(26 \%)$ & $(74 \%)$ \\
\hline \multirow{2}{*}{3} & CRL & 48 & \multirow{2}{*}{$6 \mathrm{OH}$} & \multirow{2}{*}{$3 a$} & $(65 \%)$ & $(35 \%)$ \\
\hline & AXE & $72 \mathrm{~h}$ & & & $(27 \%)$ & $(73 \%)$ \\
\hline \multirow{2}{*}{4} & CRL & $24 \mathrm{~h}$ & \multirow{2}{*}{$6 \mathrm{OH}$} & \multirow{2}{*}{$4 a$} & $(69 \%)$ & $(31 \%)$ \\
\hline & AXE & $48 \mathrm{~h}$ & & & $(24 \%)$ & $(76 \%)$ \\
\hline \multirow{4}{*}{5} & \multirow{2}{*}{ CRL } & \multirow{2}{*}{$20 \mathrm{~h}$} & $6 \mathrm{OH}$ & $5 a$ & $(80 \%)$ & \multirow{2}{*}{$(12 \%)$} \\
\hline & & & $2 \mathrm{OH}$ & $5 b$ & $(8 \%)$ & \\
\hline & \multirow{2}{*}{ AXE } & \multirow{2}{*}{$24 \mathrm{~h}$} & $6 \mathrm{OH}$ & $5 a$ & $(5 \%)$ & \multirow{2}{*}{$(55 \%)$} \\
\hline & & & $2 \mathrm{OH}$ & $5 b$ & $(40 \%)$ & \\
\hline \multirow{2}{*}{6} & CRL & $6 \mathrm{~h}$ & \multirow{2}{*}{$6 \mathrm{OH}$} & \multirow{2}{*}{$6 a$} & $(81 \%)$ & $(19 \%)$ \\
\hline & AXE & $6 \mathrm{~h}$ & & & $(24 \%)$ & $(48 \%)$ \\
\hline \multirow[b]{2}{*}{7} & CRL & $24 \mathrm{~h}$ & $6 \mathrm{OH}$ & $7 a$ & $(70 \%)$ & $(30 \%)$ \\
\hline & AXE & $24 \mathrm{~h}$ & - & - & - & - \\
\hline \multirow{2}{*}{8} & CRL & $48 \mathrm{~h}$ & \multirow{2}{*}{$6 \mathrm{OH}$} & \multirow{2}{*}{$8 a$} & $(68 \%)$ & $(32 \%)$ \\
\hline & AXE & $24 \mathrm{~h}$ & & & $(90 \%)$ & $(10 \%)$ \\
\hline
\end{tabular}

Experimental conditions: $50 \mathrm{mM} \mathrm{KH}_{2} \mathrm{PO}_{4} \mathrm{pH} 4.0$ (except for compound $8 \mathrm{pH}=5.0$ ), 20\%-30\% v/v acetonitrile, room temperature, substrate concentration $=10 \mathrm{mM}$, CRL immobilized on OC-AG and AXE immobilized on GLX-AG. 
Interestingly, for compound 5, CRL and AXE showed a different regioselectivity profile: CRL selectively deprotected the primary position (C6) giving 5a (80\%), while AXE preferred the C2 position, giving access to $5 \mathbf{b}$ in acceptable yields (40\%). These results highlighted a different and complementary selectivity behavior of the two biocatalysts towards the same substrate.

Compound 8 was selectively hydrolyzed by using AXE immobilized on GLX-AG, and the results were in agreement with those previously reported using the enzyme immobilized on acrylic epoxy carrier $[15,35]$.

These monodeprotected products are useful building blocks in the synthesis of oligosaccharides and glycoconjugates. For example, compounds obtained from $\mathbf{2 a}$ and $\mathbf{8 a}$ can be used to conjugate antigenic proteins through the thiocyanomethyl group in anomeric position. Compound 3a can be used both as acceptor or donor in further glycosylation reactions because, once used as acceptor, the product obtained can become a donor due to the good properties of S-Tol group as leaving group. Furthermore, compounds obtained by hydrolysis of 5 and 7 can be used as intermediates to prepare glycoproducts by click chemistry, thanks to their propargyl and azido groups in the anomeric position.

\subsection{Synthesis of Peracetylated Disaccharides (10-18)}

Monodeprotected monosaccharides obtained previously were further used as sugar acceptors to synthesize different disaccharides by Schmidt glycosylation reaction (Lewis acid-catalyzed glycosylation using glycosyl trichloroacetimidate as donor as reported in Scheme 2). The reaction was optimized with respect to temperature and time depending on the glycosylation position (Table 3). Man $(1 \rightarrow 6)$ man disaccharides $(\mathbf{1 0}, \mathbf{1 2}-\mathbf{1 5})$ were obtained in a range of $50 \%$ and $92 \%$ yield (except for 13: $37 \%$ yield) by using $0{ }^{\circ} \mathrm{C}$ after $2.5-4 \mathrm{~h}$. The same conditions were used also for compound $\mathbf{1 6}$ obtained in very good yield $(74 \%)$. The synthesis of $\operatorname{man}(1 \rightarrow 6) \mathrm{manSCH}_{2} \mathrm{CN}(\mathbf{1 1})$ and $\operatorname{man}(1 \rightarrow 2)$ man disaccharides required a very cold environment $\left(-63 /-70^{\circ} \mathrm{C}\right.$ ) to afford products 11, 17, and 18 in $79 \%, 52 \%$, and $80 \%$ yield, respectively (Table 3 ).

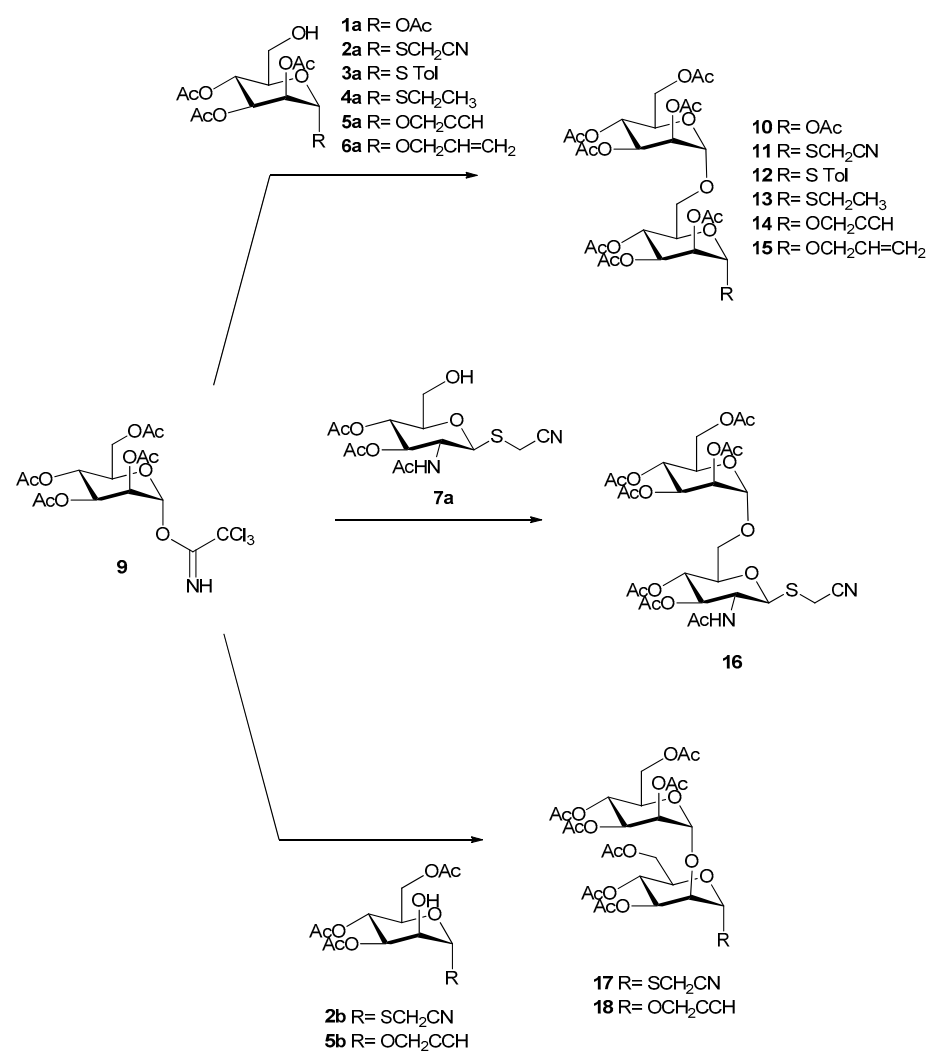

Scheme 2. Synthesis of peracetylated mannose-based disaccharides (10-18). Reaction conditions are reported in Table 3. 
Table 3. Reaction conditions for disaccharides synthesis.

\begin{tabular}{cccc}
\hline Compound & Temperature $\left({ }^{\circ} \mathbf{C}\right)$ & Reaction Time (h) & Yield (\%) \\
\hline $\mathbf{1 0}$ & 0 & 2.5 & 87 \\
$\mathbf{1 1}$ & -70 to r.t. & 4 & 79 \\
$\mathbf{1 2}$ & 0 & 3.5 & 92 \\
$\mathbf{1 3}$ & 0 & 4 & 37 \\
$\mathbf{1 4}$ & 0 & 4 & 90 \\
$\mathbf{1 5}$ & 0 & 2 & 50 \\
$\mathbf{1 6}$ & 0 & 2.5 & 74 \\
$\mathbf{1 7}$ & -63 to r.t. & 1.5 & 52 \\
$\mathbf{1 8}$ & -50 to r.t. & 18 & 80 \\
\hline
\end{tabular}

Thus, through the above described chemoenzymatic approach, a library of nine mannose-based disaccharides (10-18) with $1 \rightarrow 6$ or $1 \rightarrow 2$ linkage (Scheme 2 ), and with different anomeric reactive groups, were obtained with good yields and using only the acetyl group for protection.

\subsection{Enzymatic Hydrolysis of Peracetylated Disaccharides (10-18)}

The disaccharides prepared as previously reported (see Section 2.3) were subsequently tested as substrates for enzymatic hydrolysis with the aim to obtain selectively deprotected disaccharides that can be further used as advanced building blocks for the synthesis of complex linear and branched oligosaccharides. Both CRL and AXE were tested as catalysts (Table 4), but only AXE showed a relevant activity towards the different disaccharides 10-18 (CRL was almost completely inactive towards all these substrates).

Table 4. Regioselective enzymatic deprotection of mannose-based disaccharides (10-18) using AXE-GLX-AG.

\begin{tabular}{cccccc}
\hline Substrate & Time (h) & Position & Product & Yield (\%) $^{\mathbf{a}}$ & Conversion (\%) $^{\mathbf{b}}$ \\
\hline $\mathbf{1 0}$ & 48 & $1 \mathrm{OH}$ & $\mathbf{1 0 a}$ & 50 & 63 \\
$\mathbf{1 1}$ & 5 & $2 \mathrm{OH}$ & $\mathbf{1 1 a}$ & 23 & 53 \\
$\mathbf{1 2}$ & 57 & $2 \mathrm{OH}$ & $\mathbf{1 2 a}$ & 24 & 60 \\
$\mathbf{1 3}$ & 7 & $2 \mathrm{OH}$ & $\mathbf{1 3 a}$ & 38 & 41 \\
$\mathbf{1 4}$ & 26 & $2 \mathrm{OH}$ & $\mathbf{1 4 a}$ & 24 & 85 \\
$\mathbf{1 5}$ & 15 & $2 \mathrm{OH}$ & $\mathbf{1 5 a}$ & 52 & 84 \\
$\mathbf{1 6}$ & 168 & $2{ }^{\prime} \mathrm{OH}$ & $\mathbf{1 6 a}$ & 21 & 40 \\
$\mathbf{1 7}$ & 8.5 & $6 \mathrm{OH}$ & $\mathbf{1 7 a}$ & 16 & 46 \\
$\mathbf{1 8}$ & 24 & $6 \mathrm{OH}$ & $\mathbf{1 8 a}$ & 20 & 32 \\
\hline
\end{tabular}

Experimental conditions: $25 \mathrm{mM} \mathrm{KH}{ }_{2} \mathrm{PO}_{4} \mathrm{pH} \mathrm{4.0-5.8,30 \% -35 \%} \mathrm{v/v} \mathrm{acetonitrile,} \mathrm{room} \mathrm{temperature,} \mathrm{substrate}$ concentration $=5-10 \mathrm{mM}$, AXE immobilized on GLX-AG. ${ }^{\text {a }}$ Yield was determined by isolation and purification by flash chromatography. ${ }^{b}$ Conversion was calculated based on the isolated amount of unconverted substrate.

The hydrolysis catalyzed by AXE-GLX-AG derivative provided different results depending from the substrate as shown in Table 4 . The fully acetylated man $(1 \rightarrow 6)$ man $\mathbf{1 0}$ (Scheme 3) was deprotected at the anomeric position yielding product $10 \mathrm{a}$ with $50 \%$ of maximum yield after $48 \mathrm{~h}$ of reaction ( $63 \%$ of substrate consumption), in agreement with the results previously reported for lactose bearing an acetoxy group in anomeric position [21]. By introducing an alkyl or aryl glycoside or thioglycoside group (substrates 11-15 in Scheme 3) in anomeric position, the selectivity of AXE moved towards the C2 position allowing the production of compounds 11a-15a with yields ranging from $23 \%$ to $52 \%$. When man $(1 \rightarrow 6)$ GluNHAc 16 was submitted to hydrolysis, AXE was not able to hydrolyze the acetamido group of the anomeric sugar (GluNAc); thus, the selectivity of the enzyme moved further towards C2' position of the mannose unit at the non-reducing end (Scheme 3). However, the reaction proceeded very slowly ( $168 \mathrm{~h}$ for achieving $40 \%$ of substrate consumption) and low yields (about $20 \%$ of product $16 a$ ). 


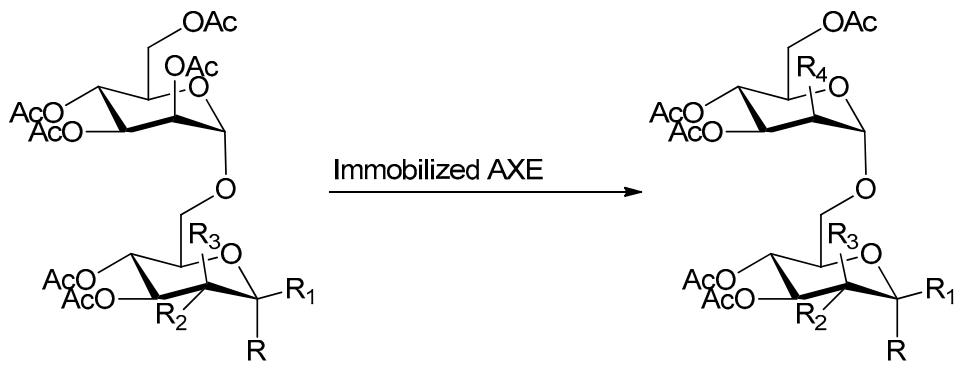

$10 \mathrm{R}=\mathrm{OAc}, \mathrm{R}_{1}=\mathrm{H}, \mathrm{R}_{2}=\mathrm{H}, \mathrm{R}_{3}=\mathrm{OAC}$

$11 \mathrm{R}=\mathrm{SCH}_{2} \mathrm{CN}, \mathrm{R}_{1}=\mathrm{H}, \mathrm{R}_{2}=\mathrm{H}, \mathrm{R}_{3}=\mathrm{OAC}$

$12 \mathrm{R}=\mathrm{STol}, \mathrm{R}_{1}=\mathrm{H}, \mathrm{R}_{2}=\mathrm{H}, \mathrm{R}_{3}=\mathrm{OAc}$

$13 \mathrm{R}=\mathrm{SCH}_{2} \mathrm{CH}_{3}, \mathrm{R}_{1}=\mathrm{H}, \mathrm{R}_{2}=\mathrm{H}, \mathrm{R}_{3}=\mathrm{OAC}$

$14 \mathrm{R}=\mathrm{OCH}_{2} \mathrm{CCH}, \mathrm{R}_{1}=\mathrm{H}, \mathrm{R}_{2}=\mathrm{H}, \mathrm{R}_{3}=\mathrm{OAC}$

$15 \mathrm{R}=\mathrm{OCH}_{2} \mathrm{CH}=\mathrm{CH}_{2}, \mathrm{R}_{1}=\mathrm{H}, \mathrm{R}_{2}=\mathrm{H}, \mathrm{R}_{3}=\mathrm{OAC}$

$16 \mathrm{R}=\mathrm{H}, \mathrm{R}_{1}=\mathrm{SCH}_{2} \mathrm{CN}, \mathrm{R}_{2}=\mathrm{NHAc}, \mathrm{R}_{3}=\mathrm{H}$ 10a $\mathrm{R}=\mathrm{OH}, \mathrm{R}_{1}=\mathrm{H}, \mathrm{R}_{2}=\mathrm{H}, \mathrm{R}_{3}=\mathrm{OAc}, \mathrm{R}_{4}=\mathrm{OAc}$

11a $\mathrm{R}=\mathrm{SCH}_{2} \mathrm{CN}, \mathrm{R}_{1}=\mathrm{H}, \mathrm{R}_{2}=\mathrm{H}, \mathrm{R}_{3}=\mathrm{OH}, \mathrm{R}_{4}=\mathrm{OAc}$

12a $\mathrm{R}=\mathrm{STol}, \mathrm{R}_{1}=\mathrm{H}, \mathrm{R}_{2}=\mathrm{H}, \mathrm{R}_{3}=\mathrm{OH}, \mathrm{R}_{4}=\mathrm{OAc}$

13a $\mathrm{R}=\mathrm{SCH}_{2} \mathrm{CH}_{3}, \mathrm{R}_{1}=\mathrm{H}, \mathrm{R}_{2}=\mathrm{H}, \mathrm{R}_{3}=\mathrm{OH}, \mathrm{R}_{4}=\mathrm{OAc}$

14a $\mathrm{R}=\mathrm{OCH}_{2} \mathrm{CCH}, \mathrm{R}_{1}=\mathrm{H}, \mathrm{R}_{2}=\mathrm{H}, \mathrm{R}_{3}=\mathrm{OH}, \mathrm{R}_{4}=\mathrm{OAC}$

15a R= OCH $\mathrm{OCH}_{2} \mathrm{CH} \mathrm{CH}_{2}, \mathrm{R}_{1}=\mathrm{H}, \mathrm{R}_{2}=\mathrm{H}, \mathrm{R}_{3}=\mathrm{OH}, \mathrm{R}_{4}=\mathrm{OAC}$

16a $\mathrm{R}=\mathrm{H}, \mathrm{R}_{1}=\mathrm{SCH}_{2} \mathrm{CN}, \mathrm{R}_{2}=\mathrm{NHAc}, \mathrm{R}_{3}=\mathrm{H}, \mathrm{R}_{4}=\mathrm{OH}$

Scheme 3. Regioselective enzymatic hydrolysis of peracetylated $1 \rightarrow 6$ disaccharides (10-16).

Similarly, when the man $(1 \rightarrow 2)$ man disaccharides $\mathbf{1 7}$ and $\mathbf{1 8}$ were tested as substrates of AXE (Scheme 4), the hydrolysis was observed for the position C6 (being position C2 involved in the glycosidic bond), yielding the products $17 \mathbf{a}$ and 18a with the thiocyanomethyl and the propargyl group in anomeric position. In these cases, the yields obtained were lower (16\% and $20 \%$, respectively) compared to the corresponding man $(1 \rightarrow 6)$ man disaccharides (compounds 11a and 15a).

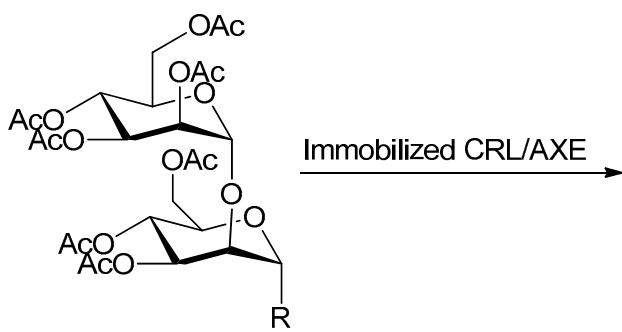

$17 \mathrm{R}=\mathrm{SCH}_{2} \mathrm{CN}$

$18 \mathrm{R}=\mathrm{OCH}_{2} \mathrm{CCH}$

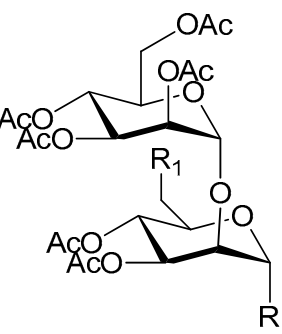

$17 \mathrm{a} \mathrm{R}=\mathrm{SCH}_{2} \mathrm{CN}, \mathrm{R}_{1}=\mathrm{OH}$

18a $\mathrm{R}=\mathrm{OCH}_{2} \mathrm{CCH}, \mathrm{R}_{1}=\mathrm{OH}$

Scheme 4. Regioselective enzymatic hydrolysis of peracetylated $1 \rightarrow 2$ disaccharides (17-18).

\section{Materials and Methods}

Reagents, chemicals, hydrophobic carrier octyl-Sepharose ${ }^{\circledR}$ CL-4B, and lipase from Candida rugosa (CRL) were purchased from Sigma-Aldrich (Milano, Italy). Acetyl xylan esterase (AXE) from Bacillus pumilus was from Dobfar (Tribiano, Italy). Sepharose ${ }^{\mathrm{TM}}$ CL-6B (agarose) was from GE Healthcare (Milan, Italy). $\alpha$-D-Mannose pentaacetate (1) was purchased from Sigma-Aldrich (Milano, Italy).

Compounds purification was performed by flash chromatography using Silica Gel high-purity grade, pore size $60 \AA$ 70-230 mesh, 63-200 $\mu \mathrm{m}$ (Sigma-Aldrich). Analytical thin layer chromatography (TLC) was performed on silica gel F254 precoated aluminium sheets $(0.2 \mathrm{~mm}$ layer, Merck, Darmstadt, Germany). Products were detected by spraying with $5 \% \mathrm{H}_{2} \mathrm{SO}_{4}$ in ethanol, followed by heating to ca. $150{ }^{\circ} \mathrm{C}$. Enzymatic reactions and activity assays were monitored by Titrator 718 stat (pH-Stat) Tritino from Metrohm (Herisau, Switzerland). Characterization of purified compounds was performed by NMR spectroscopy. NMR spectra were recorded in $\mathrm{CDCl}_{3}$ on a Bruker Advance III $400 \mathrm{MHz}$ spectrometer (Bruker Corporation, Billerica, MA, USA), available at the Centro Grandi Strumenti of the University of Pavia. All 1D and 2D NMR spectra were acquired using the standard pulse sequences available with Bruker Topspin 3.6 software package. Chemical shifts $(\delta)$ are given in ppm and were 
referenced to the solvent signals $\left(\delta_{\mathrm{H}} 7.28, \delta_{\mathrm{C}} 77.00\right)$. Signal multiplicities are abbreviated as follows: $\mathrm{s}$, singlet; $\mathrm{d}$, doublet; $\mathrm{t}$, triplet; $\mathrm{m}$, multiplet; $\mathrm{b}$, broad. Structures assignment was performed by means of 2D-COSY and HSQC and, in some cases, 2D-NOESY. Spectra analyses were carried out using Mestrenova reader software. For compounds $\mathbf{5 a}, \mathbf{5 b}, \mathbf{1 4}$, and $\mathbf{1 8}$ high resolution mass spectra (HRMS) were recorded with a Bruker Micro-TOF spectrometer in electrospray ionization (ESI) mode, using Tuning-Mix as reference. For all other compounds, mass spectra were recorded on an LCQ-DECA Thermo Finnigan Spectrometer by the ESI (Electron Spray Ionization) ionization method with an ionic source and with use of Xcalibur 2.2 software (Thermo-Finnigan, San Jose, CA, USA). Analyses were run under positive modality, and the experimental conditions were: voltage of the source $5.0 \mathrm{kV}$, voltage of the capillary $14 \mathrm{~V}$, flow of the gas 35 (arbitrary units), and temperature $200{ }^{\circ} \mathrm{C}$.

\subsection{Determination of Enzymatic Activity}

The activity of the enzymes was determined following a standard protocol by using an automatic titrator pH-Stat. The hydrolytic activity was calculated based on $\mathrm{NaOH}$ consumption ( $\mathrm{mL}$ of $\mathrm{NaOH} / \mathrm{min}$ ).

\subsubsection{Standard Activity Assay with Acetyl Xylan Esterase from Bacillus pumilus (AXE)}

The activity of AXE was determined using 1-naphtyl acetate as standard substrate [21]. The standard reaction mixture was composed of $2 \mathrm{~mL}$ of acetonitrile, $2 \mathrm{~mL}$ of 1-naphtyl acetate (50 $\mathrm{mM}$ in acetonitrile), and $16 \mathrm{~mL}$ of phosphate buffer $(25 \mathrm{mM}, \mathrm{pH} 7.0)$. The reaction was started through the addition of $100 \mu \mathrm{L}$ soluble enzyme $(49 \mathrm{mg} / \mathrm{mL})$ or $10-15 \mathrm{mg}$ of immobilized enzyme. The mixture was mechanically stirred and $\mathrm{pH}$ was maintained at 7.0 using $100 \mathrm{mM} \mathrm{NaOH}$ as titrant. Experiments were done at least in duplicate.

\subsubsection{Standard Activity Assay with Candida rugosa Lipase (CRL)}

The activity of CRL was determined using tripropionin as standard substrate [36]. The standard reaction mixture was composed of $0.6 \mathrm{~mL}$ of acetonitrile, $1 \mathrm{~mL}$ of tripropionin, and $18.4 \mathrm{~mL}$ of Tris- $\mathrm{HCl}$ ( $25 \mathrm{mM}, \mathrm{pH} 7.0)$. The reaction was started through the addition of $100 \mu \mathrm{L}$ soluble enzyme $(10 \mathrm{mg} / \mathrm{mL})$ or $10-15 \mathrm{mg}$ of immobilized enzyme. The mixture was mechanically stirred and $\mathrm{pH}$ was maintained at 7.0 using $100 \mathrm{mM} \mathrm{NaOH}$ as titrant. Experiments were done at least in duplicate.

\subsection{AXE Immobilization on Glyoxyl-Agarose (GLX-AG)}

GLX-AG was prepared as reported in literature [37]. Briefly, Sepharose ${ }^{\mathrm{TM}} \mathrm{CL}-6 \mathrm{~B}$ (agarose, $5 \mathrm{~g}$ ) was suspended in deionized $\mathrm{H}_{2} \mathrm{O}(1.4 \mathrm{~mL})$ and $\mathrm{NaOH}(1.7 \mathrm{M}, 2.4 \mathrm{~mL})$ containing $\mathrm{NaBH}_{4}(28.4 \mathrm{mg} / \mathrm{mL})$. Subsequently, glycidol $(1.7 \mathrm{~mL})$ was added dropwise, keeping the vessel at $4{ }^{\circ} \mathrm{C}$ in an ice bath. The reaction was kept under gently stirring overnight at $25^{\circ} \mathrm{C}$. After the incubation period, the suspension was filtered, and the carrier was washed abundantly with deionized $\mathrm{H}_{2} \mathrm{O}$. Oxidation was initiated by adding $\mathrm{NaIO}_{4}(100 \mathrm{mM}, 34 \mathrm{~mL})$. The reaction was carried out for $2 \mathrm{~h}$ at room temperature, and then the carrier was filtered under reduced pressure and washed abundantly with deionized $\mathrm{H}_{2} \mathrm{O}$ and stored at $4{ }^{\circ} \mathrm{C}$.

Immobilization of AXE on GLX-AG was performed following a standard protocol [38,39]. Briefly, glyoxyl-agarose was washed abundantly with $\mathrm{NaHCO}_{3}$ buffer $(50 \mathrm{mM}, \mathrm{pH} 10)$ and then filtered under reduced pressure until dryness. Soluble enzyme (50 mg or $150 \mathrm{mg}$ loading of protein per gram of carrier) was solubilized into $\mathrm{NaHCO}_{3}$ buffer $(50 \mathrm{mM}, \mathrm{pH} 10)$. Then, the carrier was added, and the suspension was allowed to stir at $25^{\circ} \mathrm{C}$ or $4{ }^{\circ} \mathrm{C}$. Finally, $\mathrm{NaBH}_{4}$ ( $1 \mathrm{mg}$ for each $100 \mathrm{mg}$ of carrier) was added to the mixture and incubated for $30 \mathrm{~min}$ to allow imino bonds reduction. The immobilized enzyme was then filtered, rinsed thoroughly with distilled water, and stored at $4{ }^{\circ} \mathrm{C}$ till use.

\subsection{AXE Immobilization on Sepabeads EC-EP/M}

Immobilization of AXE on Sepabeads EC-EP/M was performed following a standard protocol [38,39]. Briefly, Sepabeads EC-EP/M was allowed to hydrate for $1 \mathrm{~h}$ in water on a rolling shaker at $25^{\circ} \mathrm{C}$, and then it was filtered under reduced pressure until dryness. Soluble enzyme $(150 \mathrm{mg}$ loading of 
protein per gram of carrier) was solubilized into $\mathrm{KH}_{2} \mathrm{PO}_{4}$ buffer $(1 \mathrm{M}, \mathrm{pH}$ 8). Then, the carrier was added and the suspension was allowed to stir for $24 \mathrm{~h}$ at $25^{\circ} \mathrm{C}$. Subsequently, the epoxy groups were quenched with $3 \mathrm{M}$ glycine in $\mathrm{KH}_{2} \mathrm{PO}_{4}$ buffer $\left(1 \mathrm{M}, \mathrm{pH}\right.$ 8) for $18 \mathrm{~h}$ at $25^{\circ} \mathrm{C}$. The immobilized enzyme was then filtered, rinsed thoroughly with distilled water, and stored at $4{ }^{\circ} \mathrm{C}$ till use.

\subsection{CRL Immobilization on Octyl-Sepharose ${ }^{\circledR}(O C-A G)$}

The crude extract of CRL (1.5 g; loading 2500 UI per gram of carrier) was suspended in $\mathrm{KH}_{2} \mathrm{PO}_{4}$ buffer ( $25 \mathrm{mM}, \mathrm{pH}$ 7.0). The mixture was allowed to stir on the rolling shaker for $30 \mathrm{~min}$. Then, octyl-Sepharose ${ }^{\circledR}$ $(3 \mathrm{~g})$, previously conditioned with the same buffer, was added and the suspension was stirred at room temperature overnight. The enzyme derivative was filtered under reduced pressure on a Büchner funnel, rinsed thoroughly with distilled water, and stored at $4{ }^{\circ} \mathrm{C}$ till use.

\subsection{Chemical Synthesis of Monosaccharides 2-9}

Cyanomethyl 2,3,4,6-tetra-O-acetyl-1-thio- $\alpha$-D-mannopyranoside (2)

Cyanomethyl 2,3,4,6-tetra-O-acetyl-1-thio- $\alpha$-D-mannopyranoside (2) was synthesized as previously reported [40].

Briefly, 2-S-(2,3,4,6-tetra-O-acetyl- $\alpha$-D-mannopyranosyl-)-2-thiopseudourea hydrobromide (7.3 g, $0.017 \mathrm{mmol}, 1 \mathrm{eq}$.$) , sodium meta bisulphite (6.28 \mathrm{~g}, 0.034 \mathrm{mmol}, 2 \mathrm{eq}$.$) , and potassium carbonate (2.81 \mathrm{~g}$, $0.0204 \mathrm{mmol}, 1.2 \mathrm{eq})$ were dissolved in acetone/water $(50: 50,80 \mathrm{~mL})$. Subsequently, chloroacetonitrile ( $21.73 \mathrm{~mL}, 0.34 \mathrm{mmol}, 20 \mathrm{eq}$.) was added, and the reaction was incubated for $\sim 2 \mathrm{~h}$ at room temperature. The reaction mixture was monitored by TLC (ethyl acetate/ $n$-hexane $5: 5, \mathrm{Rf}=0.60$ ). Upon completion, $60 \mathrm{~mL}$ of ice water were added to the solution, and the mixture was stirred for $45 \mathrm{~min}$. The reaction was extracted with dichloromethane, and the combined organics extracts were washed with brine, filtered, dried over $\mathrm{Na}_{2} \mathrm{SO}_{4}$, and concentrated in vacuo. The mixture was then crystallized from hot methanol. A white crystalline solid was obtained ( $\mathrm{g}, 45 \%) .{ }^{1} \mathrm{H}-\mathrm{NMR}$ was in agreement with that previously reported [40].

(4-Methylphenyl) 2,3,4,6-tetra-O-acetyl-1-thio- $\alpha$-D-mannopyranoside (3)

(4-Methylphenyl) 2,3,4,6-tetra-O-acetyl-1-thio- $\alpha$-D-mannopyranoside (3) was synthesized, slightly modifying the protocol reported by Janssens J. et al. [41].

Briefly, to a mixture of 1,2,3,4,6-penta-O-acetyl- $\alpha$-D-mannopyranose (1) (3.372 g, $8.6 \mathrm{mmol}, 1$ eq.) and $p$-thiocresol $(0.955 \mathrm{~g}, 7.6 \mathrm{mmol}, 1.2 \mathrm{eq}$.) in dichloromethane $(35 \mathrm{~mL})$, boron trifluoride diethyl etherate $(700 \mu \mathrm{L}, 5.6 \mathrm{mmol}, 1.5 \mathrm{eq}$.) was added dropwise. The mixture was stirred at room temperature for $48 \mathrm{~h}$, under nitrogen atmosphere. The reaction mixture was monitored by TLC (ethyl acetate/toluene $3: 7, \mathrm{Rf}=0.57)$. The reaction mixture was then diluted with dichloromethane $(28 \mathrm{~mL})$ and washed with saturated $\mathrm{NaHCO}_{3}$ twice and water. The organic layer was dried over $\mathrm{MgSO}_{4}$. The solvent was removed, and the residue was purified by column chromatography $\left(\mathrm{SiO}_{2}\right.$, ethyl acetate/toluene 3:7). The desired product was obtained as a white solid (3.21 g, 85\%). ${ }^{1} \mathrm{H}-\mathrm{NMR}$ was in agreement with that previously reported [42].

Ethyl 2,3,4,6-tetra-O-acetyl-1-thio- $\alpha$-D-mannopyranoside (4)

Ethyl 2,3,4,6-tetra-O-acetyl-1-thio- $\alpha$-D-mannopyranoside (4) was synthesized following a slightly modified protocol reported by Calosso M. et al. [43].

Briefly, to a solution of 1,2,3,4,6-penta-O-acetyl- $\alpha$-D-mannopyranose (1) (3.062 g, $7.85 \mathrm{mmol}, 1$ eq.) in anhydrous dichloromethane, ethanethiol $(0.79 \mathrm{~mL}, 11 \mathrm{mmol}, 1.4$ eq. $)$ in the presence of $4 \AA$ molecular sieves was added. The reaction was cooled to $0{ }^{\circ} \mathrm{C}$, and $\mathrm{BF}_{3} \mathrm{OEt}_{2}(1.65 \mathrm{~mL}, 13.345 \mathrm{mmol}, 1.7$ eq.) was added dropwise. The reaction was monitored by TLC (ethyl acetate $/ n$-hexane $6: 4, \mathrm{Rf}=0.64$ ). After $7 \mathrm{~h}$, the reaction was washed with $40 \mathrm{~mL}$ of a saturated solution of $\mathrm{NaHCO}_{3}$, and the aqueous phase was washed with dichloromethane. The organic phase was dried with $\mathrm{Na}_{2} \mathrm{SO}_{4}$, filtered and concentrated 
in vacuo. The reaction crude was purified by flash chromatography $\left(\mathrm{SiO}_{2}\right.$, ethyl acetate/n-hexane 6:4). The desired product was obtained as a white solid $(2.15 \mathrm{~g}, 70 \%)$. ${ }^{1} \mathrm{H}-\mathrm{NMR}$ was in agreement with that previously reported [44].

Propargyl 2,3,4,6-tetra-O-acetyl- $\alpha$-D-mannopyranoside (5)

Propargyl 2,3,4,6-tetra-O-acetyl- $\alpha$-D-mannopyranoside (5) was synthesized following a standard procedure [45]. Briefly, 1,2,3,4,6-penta-O-acetyl- $\alpha$-D-mannopyranose (1) (1.043 g, $2.68 \mathrm{mmol}, 1$ eq.) was dissolved in anhydrous dichloromethane $(8 \mathrm{~mL})$ under nitrogen atmosphere in presence of activated molecular sieves. Propargyl alcohol $(0.156 \mathrm{~mL}, 2.68 \mathrm{mmol}, 1$ eq. $)$ was added. The mixture was cooled to $0{ }^{\circ} \mathrm{C}$, and $\mathrm{BF}_{3} \mathrm{OEt}_{2}(0.661 \mathrm{~mL}, 5.36 \mathrm{mmol}, 2$ eq. $)$ was added dropwise. The reaction mixture was allowed to warm up to room temperature and allowed to stir for 5 days. The solution was diluted with dichloromethane, washed with saturated $\mathrm{NaHCO}_{3}$ then water, dried over $\mathrm{Na}_{2} \mathrm{SO}_{4}$, and concentrated in vacuo. The reaction was monitored by TLC (ethyl acetate/ $n$-hexane 5:5, $\mathrm{Rf}=0.30$ ). Column chromatography $\left(\mathrm{SiO}_{2}\right.$, ethyl acetate/n-hexane 5:5) gave the desired compound as white solid (2.64 g, 84\%). ${ }^{1} \mathrm{H}-\mathrm{NMR}$ was in agreement with that previously reported [45].

Allyl 2,3,4,6-tetra-O-acetyl- $\alpha$-D-mannopyranoside (6)

Allyl 2,3,4,6-tetra-O-acetyl- $\alpha$-D-mannopyranoside (6) was synthesized modifying slightly the protocol reported by Balcerzak A.K. et al. [46]. Briefly, 1,2,3,4,6-penta-O-acetyl- $\alpha$-D-mannopyranose (1) $(1 \mathrm{~g}, 25.6 \mathrm{mmol}, 1$ eq. $)$ was dissolved in anhydrous dichloromethane $(8 \mathrm{~mL})$ under nitrogen atmosphere in presence of activated molecular sieves. Allyl alcohol $(0.175 \mathrm{~mL}, 25.6 \mathrm{mmol}, 1$ eq.) was added. The mixture was cooled to $0{ }^{\circ} \mathrm{C}$, and $\mathrm{BF}_{3} \mathrm{OEt}_{2}(0.633 \mathrm{~mL}, 51.2 \mathrm{mmol}, 2$ eq. $)$ was added dropwise. The reaction mixture was allowed to warm up to room temperature and allowed to stir for 7 days. The solution was diluted with dichloromethane, washed with saturated $\mathrm{NaHCO}_{3}$ and then water, dried over $\mathrm{Na}_{2} \mathrm{SO}_{4}$, and concentrated in vacuo. The reaction was monitored by TLC (ethyl acetate/ $n$-hexane 5:5, $\mathrm{Rf}=0.65)$. Column chromatography $\left(\mathrm{SiO}_{2}\right.$, ethyl acetate/n-hexane 5:5) gave the desired product as a colorless oil (610 mg, 61\%). ${ }^{1} \mathrm{H}-\mathrm{NMR}$ was in agreement with that previously reported [47].

\section{(3-Azidopropyl) 2,3,4,6-tetra-O-acetate- $\alpha$-D-mannopyranoside (7)}

(3-Azidopropyl) 2,3,4,6-tetra-O-acetate- $\alpha$-D-mannopyranoside (7) was synthesized as previously reported [34]. Briefly, 3-azido-1-propanol $(0.31 \mathrm{~mL}, 3.08 \mathrm{mmol})$ and $\mathrm{BF}_{3} \cdot \mathrm{Et}_{2} \mathrm{O}(0.49 \mathrm{~mL}, 3.87 \mathrm{mmol})$ were added to a solution of 1,2,3,4,6-penta-O-acetyl- $\alpha$-D-mannopyranose (1) (1.0 g, $2.54 \mathrm{mmol})$ in dichloromethane $(20 \mathrm{~mL})$ at $0{ }^{\circ} \mathrm{C}$, and the mixture was stirred at room temperature overnight. The reaction was monitored by TLC (ethyl acetate/ $n$-hexane 5:5, $\mathrm{Rf}=0.25$ ). The reaction mixture was quenched by adding dichloromethane $(10 \mathrm{~mL})$ and saturated $\mathrm{NaHCO}_{3}$ to neutralize the remaining $\mathrm{BF}_{3} \mathrm{Et}_{2} \mathrm{O}$. The aqueous layer was extracted by dichloromethane $(30 \mathrm{~mL})$, and the combined organic layers were washed with brine and then dried over anhydrous $\mathrm{MgSO}_{4}$, affording the crude product. The crude product was purified by flash chromatography $\left(\mathrm{SiO}_{2}\right.$, ethyl acetate $/ n$-hexane $\left.1: 1\right)$ to yield the desired product as colorless oil $(0.58 \mathrm{~g}, 50 \%) .{ }^{1} \mathrm{H}-\mathrm{NMR}$ was in agreement with that previously reported [48].

Cyanomethyl 2-acetamido-3,4,6-tri-O-acetyl-2-deoxy-1-thio- $\beta$-D-glucopyranoside (8)

Cyanomethyl 2-acetamido-3,4,6-tri-O-acetyl-2-deoxy-1-thio- $\alpha$-D-glucopyranoside (8) was synthesized as reported by Zheng $C$. et al. [15]. Briefly, 1-thiourea-2-acetamido-3,4,6,-tri-O-acetyl-2-deoxy- $\alpha$-Dglucopyranoside $(245 \mathrm{mg}, 0.554 \mathrm{mmol})$ was dissolved in 1:1 water:acetone mixture $(2.6 \mathrm{~mL})$, and sodium meta bisulphite $(0.212 \mathrm{~g}, 1.115 \mathrm{mmol})$, potassium carbonate $(0.093 \mathrm{~g}, 0.672 \mathrm{mmol})$ and chloroacetonitrile $(0.712 \mathrm{~mL}, 20$ eq.) were added. The mixture was stirred at room temperature, and reaction was monitored by TLC (dichloromethane/methanol 9:1, $\mathrm{Rf}=0.64$ ). Upon completion, $8 \mathrm{~mL}$ of ice water were added to the solution that was stirred for $45 \mathrm{~min}$. The reaction was extracted with dichloromethane, and the combined organics extracts were washed with brine and dried over anhydrous $\mathrm{Na}_{2} \mathrm{SO}_{4}$ and concentrated in vacuo. The reaction crude was purified by flash chromatography $\left(\mathrm{SiO}_{2}\right.$, dichloromethane/methanol 
95:5). The desired product was obtained as a white solid (230 mg, 98\%). ${ }^{1} \mathrm{H}-\mathrm{NMR}$ was in agreement with that previously reported [15].

\section{2,3,4,6-Tetra-O-acetyl- $\alpha$-D-mannopyranosyl trichloracetimidate (9)}

2,3,4,6-Tetra-O-acetyl- $\alpha$-D-mannopyranosyl trichloracetimidate (9) was synthesized following the procedure reported by Ekholm F.S. et al. [49]. Briefly, trichloroacetonitrile ( $4.97 \mathrm{~mL}, 49.55 \mathrm{mmol}$, 5 eq.) and 1,8-diazabicyclo-[5,4,0]-7-undecene (DBU, $0.74 \mathrm{~mL}, 4.95 \mathrm{mmol}, 0.5$ eq.) were added to a solution of 2,3,4,6-tetra-O-acetyl-D-mannopyranose (1b) $(3.45 \mathrm{~g}, 9.91 \mathrm{mmol}, 1$ eq. $)$ in anhydrous dichloromethane $(30 \mathrm{~mL})$ at $0{ }^{\circ} \mathrm{C}$ under nitrogen atmosphere. The mixture was stirred for $3 \mathrm{~h}$ at $0{ }^{\circ} \mathrm{C}$ and then concentrated in vacuo. The reaction mixture was monitored by TLC (ethyl acetate $/ n$-hexane $5: 5$, $\mathrm{Rf}=0.8)$ and purified by flash chromatography $\left(\mathrm{SiO}_{2}\right.$, ethyl acetate/n-hexane 5:5). The desired product was obtained as a yellow sticky solid $(3.89 \mathrm{~g}, 80 \%) .{ }^{1} \mathrm{H}-\mathrm{NMR}$ was in agreement with that previously reported [49].

\subsection{Enzymatic Deprotection of Monosaccharides 1-8}

The deacetylated monosaccharides were produced following a general procedure of hydrolysis.

The substrates (10 mM final concentration) were dissolved in acetonitrile (20\%-30\% v/v depending on substrate solubility) under magnetic stirring, and then phosphate buffer (50 mM, pH 4.0-5.0) was added slowly. The reaction was started through the addition of immobilized CRL and/or AXE, previously conditioned with reaction buffer. The reactions were performed at $25{ }^{\circ} \mathrm{C}$ under mechanical stirring; the $\mathrm{pH}$ of the solution was maintained constant by automatic titration. Reaction course was monitored by TLC.

After complete consumption of the starting substrate or before an excessive formation of undesired products, the reactions were stopped by enzymatic derivative filtration on Büchner funnel. Acetonitrile was evaporated under reduced pressure, and the solution was brined and extracted with ethyl acetate. The organic layers were dried over anhydrous $\mathrm{Na}_{2} \mathrm{SO}_{4}$, filtered, and concentrated in vacuo. The mixture obtained was purified by flash chromatography.

\section{1,2,3,4-Tetra-O-acetyl- $\alpha$-D-mannopyranose (1a)}

1,2,3,4,6-Penta-O-acetyl- $\alpha$-D-mannopyranose (1) was hydrolyzed to the corresponding 1,2,3,4-tetra-Oacetyl- $\alpha$-D-mannopyranose (1a) by CRL-OC-AG as reported by Bavaro T. et al. [17]. ${ }^{1} \mathrm{H}-\mathrm{NMR}$ was in agreement with that previously reported [50].

\section{2,3,4,6-Tetra-O-acetyl- $\alpha$-D-mannopyranose (1b)}

1,2,3,4,6-Penta-O-acetyl- $\alpha$-D-mannopyranose (1) (30 mg, $5 \mathrm{mM})$ was hydrolyzed to the corresponding 2,3,4,6-tetra-O- acetyl- $\alpha$-D-mannopyranose (1b) by AXE-GLX-AG. ${ }^{1} \mathrm{H}-\mathrm{NMR}$ was in agreement with that previously reported [49].

Cyanomethyl 2,3,4-tri-O-acetyl-1-thio- $\alpha$-D-mannopyranoside (2a)

Cyanomethyl 2,3,4,6-tetra-O-acetyl-1-thio- $\alpha$-D-mannopyranoside (2) was hydrolyzed to the corresponding cyanomethyl-2,3,4-tri-O-acetyl-1-thio- $\alpha$-D-mannopyranoside (2a) by CRL-OC-AG as reported by Bavaro T. et al. [17].

${ }^{1} \mathrm{H}-\mathrm{NMR}$ was in agreement with that previously reported [17].

Cyanomethyl 3,4,6-tri-O-acetyl-1-thio- $\alpha$-D-mannopyranoside (2b)

Cyanomethyl 2,3,4,6-tetra-O-acetyl-1-thio- $\alpha$-D-mannopyranoside (2) was hydrolyzed to the corresponding cyanomethyl 3,4,6-tri-O-acetyl-1-thio- $\alpha$-D-mannopyranoside (2b) by CRL-OC-AG as reported by Bavaro T. et al. [17].

${ }^{1} \mathrm{H}-\mathrm{NMR}$ was in agreement with that previously reported [17].

(4-Methylphenyl) 2,3,4-tri-O-acetyl-1-thio- $\alpha$-D-mannopyranoside (3a) 
(4-Methylphenyl) 2,3,4,6-tetra-O-acetyl-1-thio- $\alpha$-D-mannopyranoside (3) was hydrolyzed to the corresponding (4-methylphenyl) 2,3,4-tri-O-acetyl-1-thio- $\alpha$-D-mannopyranoside (3a) following the general procedure for enzymatic hydrolysis: substrate $(1 \mathrm{~g}, 10 \mathrm{mM})$ was solubilized in $255 \mathrm{~mL}$ of phosphate buffer $50 \mathrm{mM} \mathrm{pH} 4.0$ and $30 \% v / v$ of acetonitrile. The reaction was started through addition of CRL-OC-AG (7000 UI). The reaction mixture was monitored by TLC (ethyl acetate/ $n$-hexane $6: 4$ ) and purified by flash chromatography $\left(\mathrm{SiO}_{2}\right.$, ethyl acetate $/ n$-hexane $\left.6: 4, \mathrm{Rf}=0,56\right)$. The desired product was obtained as a white solid. (590 $\mathrm{mg}, 65 \%)$.

${ }^{1} \mathrm{H}-\mathrm{NMR}\left(400 \mathrm{MHz}, \mathrm{CDCl}_{3}\right): \delta 7.38(\mathrm{~d}, 2 \mathrm{H}, J=8.0 \mathrm{~Hz}, \mathrm{Ar}), 7.12(\mathrm{~d}, 2 \mathrm{H}, J=8.0 \mathrm{~Hz}, \mathrm{Ar}), 5.50(\mathrm{~s}, 1 \mathrm{H})$, $5.42(\mathrm{~s}, 1 \mathrm{H}), 5.30-5.35(\mathrm{~m}, 2 \mathrm{H}), 4.30(\mathrm{~m}, 1 \mathrm{H}), 3.7(\mathrm{~m}, 2 \mathrm{H}), 2.32\left(\mathrm{~s}, 3 \mathrm{H}, \mathrm{Ph}_{-} \mathrm{CH}_{3}\right), 2.13,2.09,2.02(3 \mathrm{~s}, 9 \mathrm{H}$, OAc).

${ }^{13} \mathrm{C}-\mathrm{NMR}\left(300 \mathrm{MHz}, \mathrm{CDCl}_{3}\right)$ : 170.74, 169.97, $169.82\left(\mathrm{COOCH}_{3}\right), 138.49,132.67,130.04,128.83(\mathrm{Ar})$, 86.12, 71.74, 70.98, 69.21, 66.62, 61.30, $21.12\left(\mathrm{Ph}_{-} \mathrm{CH}_{3}\right), 20.87,20.75,20.66\left(\mathrm{COOCH}_{3}\right)$.

MS: $m / z=435.13\left[\mathrm{M}+\mathrm{Na}^{+}\right]$(calculated 435.45).

Ethyl 2,3,4-tri-O-acetyl-1-thio- $\alpha$-D-mannopyranoside (4a)

Ethyl 2,3,4,6-tetra-O-acetyl-1-thio- $\alpha$-D-mannopyranoside (4) was hydrolyzed to the corresponding ethyl 2,3,4-tri-O-acetyl-1-thio- $\alpha$-D-mannopyranoside (4a) following the general procedure for enzymatic hydrolysis: substrate $(120 \mathrm{mg}, 10 \mathrm{mM})$ was solubilized in $30.6 \mathrm{~mL}$ of phosphate buffer $50 \mathrm{mM} \mathrm{pH} 4.0$ and $30 \% v / v$ of acetonitrile. The reaction was started through addition of CRL-OC-AG (500 UI). The reaction mixture was monitored by TLC (ethyl acetate/n-hexane 6:4) and purified by flash chromatography $\left(\mathrm{SiO}_{2}\right.$, ethyl acetate $/ n$-hexane $6: 4, \mathrm{Rf}=0.46)$. The desired product was obtained as a colorless oil $(56.8 \mathrm{mg}, 53 \%)$.

${ }^{1} \mathrm{H}-\mathrm{NMR}\left(400 \mathrm{~Hz}, \mathrm{CDCl}_{3}\right): \delta 5.36-5.28(\mathrm{~m}, 4 \mathrm{H}, \mathrm{H}-1, \mathrm{H}-2, \mathrm{H}-3, \mathrm{H}-4), 4.16-4.14(\mathrm{~m}, 1 \mathrm{H}, \mathrm{H}-5), 3.70-$ $3.67(\mathrm{~m}, 2 \mathrm{H}, \mathrm{H}-6 \mathrm{ab}), 2.67-2.62\left(\mathrm{~m}, 2 \mathrm{H}, \mathrm{SCH}_{2} \mathrm{CH}_{3}\right), 2.09,2.02,1.93(3 \mathrm{~s}, 9 \mathrm{H}, \mathrm{OAc}), 1.30\left(\mathrm{t}, 3 \mathrm{H}, \mathrm{SCH}_{2} \mathrm{CH}_{3}\right)$.

${ }^{13} \mathrm{C}-\mathrm{NMR}\left(400 \mathrm{~Hz}, \mathrm{CDCl}_{3}\right): \delta 170.93,170.07,169.79\left(\mathrm{COOCH}_{3}\right), 82.15(\mathrm{C}-1), 71.27,71.06,69.27$, $66.69,61.23$ (5C, ring carbon), $25.39\left(\mathrm{SCH}_{2} \mathrm{CH}_{3}\right), 20.91,20.74,20.65\left(\mathrm{COOCH}_{3}\right), 14.68\left(\mathrm{SCH}_{2} \mathrm{CH}_{3}\right)$.

MS: $m / z=373.10\left[\mathrm{M}+\mathrm{Na}^{+}\right]$(calculated 373.38).

Propargyl 2,3,4-tri-O-acetyl- $\alpha$-D-mannopyranoside (5a)

Propargyl 2,3,4,6-tetra-O-acetyl- $\alpha$-D-mannopyranoside (5) was hydrolyzed to the corresponding propargyl 2,3,4-tri-O-acetyl- $\alpha$-D-mannopyranoside (5a) following the general procedure for enzymatic hydrolysis: substrate $(500 \mathrm{~g}, 10 \mathrm{mM})$ was solubilized in $255 \mathrm{~mL}$ of phosphate buffer $50 \mathrm{mM} \mathrm{pH} 4.0$ and $30 \% v / v$ of acetonitrile. The reaction was started through addition of CRL-OC-AG (7000 UI). The reaction mixture was monitored by TLC (ethyl acetate/n-hexane $6: 4, \mathrm{Rf}=0.37$ ) and purified by flash chromatography $\left(\mathrm{SiO}_{2}\right.$, ethyl acetate/ $n$-hexane 5:5). The desired product was obtained as a white solid (311 $\mathrm{mg}, 80 \%)$.

${ }^{1} \mathrm{H}-\mathrm{NMR}\left(400 \mathrm{MHz}, \mathrm{CDCl}_{3}\right): \delta 5.33(\mathrm{dd}, 1 \mathrm{H}, J=3.4,10.3 \mathrm{~Hz}, \mathrm{H}-3), 5.27-5.16(\mathrm{~m}, 2 \mathrm{H}, \mathrm{H}-2, \mathrm{H}-4)$, $4.98(\mathrm{~s}, 1 \mathrm{H}, \mathrm{H}-1), 4.21\left(\mathrm{~d}, 2 \mathrm{H}, J=2.4 \mathrm{~Hz}, \mathrm{OCH}_{2} \mathrm{C} \equiv \mathrm{CH}\right), 3.78-3.72(\mathrm{~m}, 1 \mathrm{H}, \mathrm{H}-5), 3.65(\mathrm{dd}, 1 \mathrm{H}, J=2.4,12.7$ $\left.\mathrm{Hz}, \mathrm{H}-6_{\mathrm{a}}\right), 3.56\left(\mathrm{dd}, 1 \mathrm{H}, J=4.23,12.7 \mathrm{~Hz}, \mathrm{H}-6_{\mathrm{b}}\right), 2.41(\mathrm{t}, 1 \mathrm{H}, J=2.4 \mathrm{~Hz}, \mathrm{C} \equiv \mathrm{CH}), 2.17-2.09-2.02(3 \mathrm{~s}, 9 \mathrm{H}$, $\mathrm{CH}_{3} \mathrm{COO}$ ).

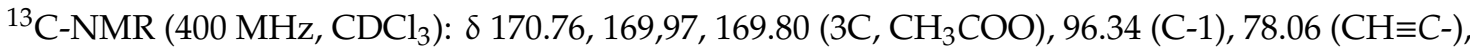
75.50 ( $\mathrm{CH} \equiv \mathrm{C}-)$, 71.14, 69.42, 68.72, 66.34, 61.16, 54.96( $\left.\mathrm{CH} \equiv \mathrm{CCH}_{2}\right), 20.84,20.72,20.66\left(3 \mathrm{C}, \mathrm{CH}_{3} \mathrm{COO}\right)$.

HRMS: $m / z=367.0996\left[\mathrm{M}+\mathrm{Na}^{+}\right]$(calculated 367.100).

Propargyl 3,4,6-tri-O-acetyl- $\alpha$-D-mannopyranoside (5b)

Propargyl 2,3,4,6-tetra-O-acetyl- $\alpha$-D-mannopyranoside (5) was hydrolyzed to the corresponding propargyl 3,4,6-tri-O-acetyl- $\alpha$-D-mannopyranoside $(5 \mathbf{b})$ following the general procedure for enzymatic hydrolysis: substrate $(500 \mathrm{mg}, 10 \mathrm{mM}$ ) was solubilized in $234 \mathrm{~mL}$ of phosphate buffer $50 \mathrm{mM} \mathrm{pH} 4.0$ and $30 \% v / v$ of acetonitrile. The reaction was started through addition of immobilized AXE (787.5 UI). The reaction mixture was monitored by TLC (ethyl acetate $/ n$-hexane $6: 4, \mathrm{Rf}=0.41$ ) and purified by flash chromatography $\left(\mathrm{SiO}_{2}\right.$, ethyl acetate/n-hexane 6:4). The desired product was obtained as a white sticky solid (178 mg, 40\%). 
${ }^{1} \mathrm{H}-\mathrm{NMR}\left(300 \mathrm{MHz}, \mathrm{CDCl}_{3}\right): \delta 5.29(\mathrm{t}, 1 \mathrm{H}, J=9.9 \mathrm{~Hz}, \mathrm{H}-4), 5.17(\mathrm{dd}, 1 \mathrm{H}, J=9.9,3.2 \mathrm{~Hz}, \mathrm{H}-3), 5.01$ $(\mathrm{d}, 1 \mathrm{H}, J=1.8 \mathrm{~Hz}, \mathrm{H}-1), 4-26-4.15\left(\mathrm{~m}, 3 \mathrm{H}, \mathrm{H}-6_{\mathrm{a}}, \mathrm{OCH}_{2} \mathrm{C} \equiv \mathrm{CH}\right), 4.06(\mathrm{~d}, 1 \mathrm{H}, J=2.5 \mathrm{~Hz} \mathrm{H}-6), 4.02(\mathrm{~m}, 1 \mathrm{H}$, $\mathrm{H}-2), 3.90(\mathrm{~m}, 1 \mathrm{H}, \mathrm{H}-5), 2.43(\mathrm{t}, 1 \mathrm{H}, \mathrm{J}=2.5 \mathrm{~Hz}, \mathrm{C} \equiv \mathrm{CH}), 2.02,2.01,1.97\left(3 \mathrm{~s}, 9 \mathrm{H}, \mathrm{COCH}_{3}\right)$.

${ }^{13} \mathrm{C}-\mathrm{NMR}\left(300 \mathrm{MHz}, \mathrm{CDCl}_{3}\right): \delta 170.85,169.99,169.89$ (3C, $\left.\mathrm{CH}_{3} \mathrm{COO}\right), 98.16(\mathrm{C}-1), 78.30(\mathrm{CH} \equiv \mathrm{C}-)$, 75.33 ( $\mathrm{CH} \equiv \mathrm{C}-)$, 71.53 (C-3), 69.02, 68.83 (C-2 C-5), 66.12 (C-4), 62.35 (C-6), 54.77 ( $\left.\mathrm{CH} \equiv \mathrm{C}-\mathrm{CH}_{2}-\mathrm{O}\right), 20.83$, 20.73, 20.67 (3C, $\left.\mathrm{CH}_{3} \mathrm{COO}\right)$.

HRMS: $m / z=367.100\left[\mathrm{M}+\mathrm{Na}^{+}\right]$(calculated 367.100).

Allyl 2,3,4-tri-O-acetyl- $\alpha$-D-mannopyranoside (6a)

Allyl 2,3,4,6-tetra-O-acetyl- $\alpha$-D-mannopyranoside (6) was hydrolyzed to the corresponding allyl 2,3,4-tri-O-acetyl- $\alpha$-D-mannopyranoside (6a) following the general procedure for enzymatic hydrolysis: substrate $(300 \mathrm{mg}, 10 \mathrm{mM}$ ) was solubilized in $77.3 \mathrm{~mL}$ of phosphate buffer $50 \mathrm{mM} \mathrm{pH} 4.0$ and $30 \% \mathrm{v} / \mathrm{v}$ of acetonitrile. The reaction was started through addition of CRL-OC-AG (4372.5 UI). The reaction mixture was monitored by TLC (ethyl acetate/ $n$-hexane $5: 5, \mathrm{Rf}=0.4$ ) and purified by flash chromatography $\left(\mathrm{SiO}_{2}\right.$, ethyl acetate/ $n$-hexane 5:5). The desired product was obtained as a colorless oil $(214 \mathrm{mg}, 80 \%)$. ${ }^{1} \mathrm{H}-\mathrm{NMR}$ was in agreement with that previously reported [51].

(3-Azidopropyl) 2,3,4-tri-O-acetate- $\alpha$-D-mannopyranoside (7a)

(3-Azidopropyl) 2,3,4,6-tetra-O-acetate- $\alpha$-D-mannopyranoside (7) was hydrolyzed to the corresponding (3-azidopropyl) 2,3,4-tri-O-acetate- $\alpha$-D-mannopyranoside (7a) by CRL-OC-AG as reported by Li Z. et al. [34]. ${ }^{1} \mathrm{H}-\mathrm{NMR}$ was in agreement with those previously reported [34].

Cyanomethyl 2-acetamido-3,4-di-O-acetyl-2-deoxy-1-thio- $\beta$-D-glucopyranoside (8a)

Cyanomethyl 2-acetamido-3,4,6-tri- $O$-acetyl- $\beta$-D-glucopyranoside (8) was hydrolyzed to the corresponding 1-thiocyanomethyl-2-acetamido-3,4-di-O-acetyl- $\beta$-D-glucopyranoside (8a) by CRL-OC-AG as reported by Zheng C. et al. [15]. ${ }^{1} \mathrm{H}-\mathrm{NMR}$ was in agreement with that previously reported [15].

\subsection{Chemical Synthesis of Disaccharides $\mathbf{1 0 - 1 8}$}

$2^{\prime}, 3^{\prime}, 4^{\prime}, 6^{\prime}$-Tetra-O-acetyl- $\alpha$-D-mannopyranosyl-(1 $\left.\rightarrow 6\right)-1,2,3,4$-tetra-O-acetyl- $\alpha$-D-mannopyranose (10)

2,3,4,6-Tetra-O-acetyl- $\alpha$-D-mannopyranosyl trichloracetimidate (9) (3.77 g, $7.662 \mathrm{mmol}, 1.6 \mathrm{eq}$.) and 1,2,3,4-tetra-O-acetyl- $\alpha$-D-mannopyranose (1a) $(1.67 \mathrm{~g}, 4.798 \mathrm{mmol}, 1$ eq.) were dissolved in dry dichloromethane $(50 \mathrm{~mL})$ in presence of activated molecular sieves and cooled to $0{ }^{\circ} \mathrm{C}$ under nitrogen atmosphere. $\mathrm{BF}_{3} \mathrm{OEt}_{2}(591 \mu \mathrm{L}, 4.798 \mathrm{mmol}, 1$ eq.) was added, and the mixture was stirred at room temperature for $2.5 \mathrm{~h}$. The reaction was quenched with triethylamine $(668 \mu \mathrm{L}, 4.798 \mathrm{mmol}$, 2 eq.), stirred for $5 \mathrm{~min}$, filtered, and concentrated in vacuo. The reaction mixture was monitored by TLC (dichloromethane/methanol 9:1, $\mathrm{Rf}=0.89)$ and purified by flash chromatography $\left(\mathrm{SiO}_{2}\right.$, dichloromethane/methanol 9:1). The desired product was obtained as a white solid ( $2.83 \mathrm{~g}, 87 \%)$. ${ }^{1} \mathrm{H}-\mathrm{NMR}$ was in agreement with that previously reported [52].

Cyanomethyl $\left(2^{\prime}, 3^{\prime}, 4^{\prime}, 6^{\prime}\right.$-tetra-O-acetyl- $\alpha$-D-mannopyranosyl)-(1 $\left.\rightarrow 6\right)-2,3,4$-tri-O-acetyl-1-thio- $\alpha$-Dmannopyranoside (11)

Cyanomethyl $\left(2^{\prime}, 3^{\prime}, 4^{\prime}, 6^{\prime}\right.$-tetra-O-acetyl- $\alpha$-D-mannopyranosyl)-(1 $\left.\rightarrow 6\right)-2,3,4$-tri-O-acetyl-1-thio- $\alpha$-Dmannopyranoside (11) was synthesized as reported by Bavaro T. et al. [17].

Briefly, 2,3,4,6-tetra-O-acetyl- $\alpha$-D-mannopyranosyl trichloracetimidate (9) (226 mg, $0.460 \mathrm{mmol}$, 2 eq.) and cyanomethyl 3,4,6-tri-O-acetyl-1-thio- $\alpha$-D-mannopyranoside (2a) $(83 \mathrm{mg}, 0.230 \mathrm{mmol}, 1$ eq.) were dissolved in dry dichloromethane $(5 \mathrm{~mL})$ in presence of activated molecular sieves and cooled to $-70{ }^{\circ} \mathrm{C}$ with dry ice under nitrogen atmosphere. $\mathrm{BF}_{3} \mathrm{OEt}_{2}(56.6 \mu \mathrm{L}, 0.460 \mathrm{mmol}, 2$ eq.) was added, and the mixture was stirred at room temperature for $4 \mathrm{~h}$. The reaction was quenched with triethylamine $(64.2 \mu \mathrm{L}, 0.460 \mathrm{mmol}, 2 \mathrm{eq}$.), stirred for $5 \mathrm{~min}$, filtered, and concentrated in vacuo. The reaction mixture was monitored by TLC (ethyl acetate/ $n$-hexane $5: 5, \mathrm{Rf}=0.32$ ) and purified by flash chromatography 
$\left(\mathrm{SiO}_{2}\right.$, ethyl acetate/ $n$-hexane 5:5). The desired product was obtained as a white solid (125 mg, 79\%). ${ }^{1} \mathrm{H}-\mathrm{NMR}$ was in agreement with that previously reported [17].

(4-Methylphenyl) $\left(2^{\prime}, 3^{\prime}, 4^{\prime}, 6^{\prime}\right.$-tetra-O-acetyl- $\alpha$-D-mannopyranosyl)-(1 $\left.\rightarrow 6\right)-2,3,4$-tri-O-acetyl-1-thio- $\alpha$-Dmannopyranoside (12)

2,3,4,6-Tetra-O-acetyl- $\alpha$-D-mannopyranosyl trichloracetimidate (9) (366 mg, $0.743 \mathrm{mmol}, 2.5$ eq.) and (4-methylphenyl) 2,3,4-tri-O-acetyl-1-thio- $\alpha$-D-mannopyranoside (3a) $(140 \mathrm{mg}, 0.298 \mathrm{mmol}, 1$ eq.) were dissolved in dry dichloromethane $(7 \mathrm{~mL})$ in presence of $4 \AA$ molecular sieves and cooled to $0{ }^{\circ} \mathrm{C}$ under nitrogen atmosphere. $\mathrm{BF}_{3} \mathrm{OEt}_{2}(73.5 \mu \mathrm{L}, 0.596 \mathrm{mmol}, 2$ eq.) was added, and the mixture was stirred at $0{ }^{\circ} \mathrm{C}$ for $3.5 \mathrm{~h}$. The reaction was quenched with triethylamine $(83.2 \mu \mathrm{L}, 0.596 \mathrm{mmol}$, 2 eq.), stirred for $5 \mathrm{~min}$, filtered, and concentrated in vacuo. The reaction mixture was monitored by TLC (ethyl acetate/ $n$-hexane $5: 5, \mathrm{Rf}=0.28)$ and purified by flash chromatography $\left(\mathrm{SiO}_{2}\right.$, ethyl acetate/n-hexane 5:5). The desired product was obtained as a white solid (204 $\mathrm{mg}, 92 \%)$.

${ }^{1} \mathrm{H}-\mathrm{NMR}\left(400 \mathrm{MHz}, \mathrm{CDCl}_{3}\right): \delta 7.30(\mathrm{~d}, 2 \mathrm{H} \mathrm{J}=8.0 \mathrm{~Hz}, \mathrm{Ar}), 7.08(\mathrm{~d}, 2 \mathrm{H}, J=8.0 \mathrm{~Hz}, \mathrm{Ar}), 5.50(\mathrm{dd}$, $J=1.7,3.2 \mathrm{~Hz}, 1 \mathrm{H}, \mathrm{H}-3), 5.42-5.20$ (m, 6H, H-4, H-2' , H-3' , H-2, H-1, H-4'), 4.84 (d, 1H, J = $1.5 \mathrm{~Hz}$, $\left.\mathrm{H}-1^{\prime}\right), 4.43-4.38(\mathrm{~m}, 1 \mathrm{H}, \mathrm{H}-5), 4.21\left(\mathrm{dd}, 1 \mathrm{H}, J=5.0,12.2 \mathrm{~Hz}, \mathrm{H}-6^{\prime}{ }_{\mathrm{a}}\right), 3.99\left(\mathrm{dd}, 1 \mathrm{H}, J=12.3,2.4 \mathrm{~Hz}, \mathrm{H}-6^{\prime}{ }_{\mathrm{b}}\right)$, 3.95-3.88 (m, 1H, H-5'), $3.74\left(\mathrm{dd}, 1 \mathrm{H}, J=11.3,5.0 \mathrm{~Hz}, \mathrm{H}-6_{\mathrm{a}}\right), 3.59\left(\mathrm{dd}, 1 \mathrm{H}, J=11.3,2.7 \mathrm{~Hz}, \mathrm{H}-6_{\mathrm{b}}\right), 2.25$ (s, 3H, $\left.\mathrm{CH}_{3}-\mathrm{Ar}\right), 2.08,2.09,2.02,2.02,1.99,1.95,1.92\left(7 \mathrm{~s}, 21 \mathrm{H}, \mathrm{COCH}_{3}\right)$.

${ }^{13} \mathrm{C}-\mathrm{NMR}\left(400 \mathrm{MHz}, \mathrm{CDCl}_{3}\right): \delta 170.60,170.14,169.90,169.87,169.74,169.72,169.56\left(7 \mathrm{C}, \mathrm{CH}_{3} \mathrm{COO}\right)$, 138.34, 132.58, 130.08, 129.08 (Ar), $97.98\left(\mathrm{C}-1^{\prime}\right), 86.17$ (C-1), 70.91 (C-3), 70.22 (C-5), 69.44, 69.31, 69.07, 68.62 (C-5'), 66.85 (C-6), 66.65, 66.00, 62.31 (C-6'), 21.13( $\left.\mathrm{CH}_{3}-\mathrm{Ar}\right), 20.85,20.78,20.75,20.72,20.72,20.66$, $20.62\left(7 \mathrm{C}, \mathrm{CH}_{3} \mathrm{COO}\right)$.

MS: $m / z=765.18\left[\mathrm{M}+\mathrm{Na}^{+}\right]$(calculated 765.20).

Ethyl (2', $3^{\prime}, 4^{\prime}, 6^{\prime}$-tetra-O-acetyl- $\alpha$-D-mannopyranosyl)-(1 $\left.\rightarrow 6\right)$-2,3,4-tri-O-acetyl-1-thio- $\alpha$-Dmannopyranoside (13)

2,3,4,6-Tetra-O-acetyl- $\alpha$-D-mannopyranosyl trichloracetimidate (9) (58.7 $\mathrm{mg}, 0.119 \mathrm{mmol}, 1$ eq.) and ethyl 2,3,4-tri-O-acetyl-1-thio- $\alpha$-D-mannopyranoside ( $4 \mathbf{a})(41.8 \mathrm{mg}, 0.119 \mathrm{mmol}, 1$ eq. $)$ were dissolved in dry dichloromethane $(1 \mathrm{~mL})$ in presence of $4 \AA$ molecular sieves and cooled to $0{ }^{\circ} \mathrm{C}$ under nitrogen atmosphere. $\mathrm{BF}_{3} \mathrm{OEt}_{2}(14.7 \mu \mathrm{L}, 0.119 \mathrm{mmol}, 1$ eq.) was added, and the mixture was stirred at room temperature for $4 \mathrm{~h}$. The reaction was quenched with triethylamine ( $17 \mu \mathrm{L}, 0.119 \mathrm{mmol}, 1$ eq.), stirred for $5 \mathrm{~min}$, filtered, and concentrated in vacuo. The reaction mixture was monitored by TLC (dichloromethane/acetone 9:1, $\mathrm{Rf}=0.71)$ and purified by flash chromatography $\left(\mathrm{SiO}_{2}\right.$, dichloromethane/acetone 9:1). The desired product was obtained as a white solid ( $28 \mathrm{mg}, 37 \%)$.

${ }^{1} \mathrm{H}-\mathrm{NMR}\left(400 \mathrm{MHz}, \mathrm{CDCl}_{3}\right): \delta 5.38-5.22$ (m, 7H, H-2' $\left., \mathrm{H}^{\prime} 3^{\prime}, \mathrm{H}-4^{\prime}, \mathrm{H}-1, \mathrm{H}-2, \mathrm{H}-3, \mathrm{H}-4\right), 4.85$ (d, $1 \mathrm{H}$, $\left.J=1.7 \mathrm{~Hz}, \mathrm{H}-1^{\prime}\right), 4.39(\mathrm{ddd}, 1 \mathrm{H}, J=9.1,6.4,2.3 \mathrm{~Hz}, \mathrm{H}-5), 4.25\left(\mathrm{dd}, 1 \mathrm{H}, J=12.2,5.4 \mathrm{~Hz}, \mathrm{H}-6^{\prime}{ }_{\mathrm{a}}\right), 4.16$ $\left(\mathrm{dd}, 1 \mathrm{H}, J=12.2,2.4 \mathrm{~Hz}, \mathrm{H}-6^{\prime}{ }_{\mathrm{b}}\right), 4.06\left(\mathrm{ddd}, 1 \mathrm{H}, J=9.5,5.4,2.4 \mathrm{~Hz}, 1 \mathrm{H}, \mathrm{H}-5^{\prime}\right), 3.82(\mathrm{dd}, 1 \mathrm{H}, J=10.9,6.4$ $\left.\mathrm{Hz}, \mathrm{H}-6_{\mathrm{a}}\right), 3.56\left(\mathrm{dd}, 1 \mathrm{H}, J=10.8,2.4 \mathrm{~Hz}, \mathrm{H}-6_{\mathrm{b}}\right), 2.74-2.63\left(\mathrm{~m}, 2 \mathrm{H}, \mathrm{SCH}_{2} \mathrm{CH}_{3}\right), 2.18,2.17,2.13,2.08,2.05$, $2.00,1.99\left(7 \mathrm{~s}, 21 \mathrm{H}, \mathrm{COCH}_{3}\right), 1.34\left(\mathrm{t}, 3 \mathrm{H}, \mathrm{J}=7.4, \mathrm{SCH}_{2} \mathrm{CH}_{3}\right)$.

${ }^{13} \mathrm{C}-\mathrm{NMR}\left(400 \mathrm{MHz}, \mathrm{CDCl}_{3}\right): \delta 170.61,170.05,169.99,169.88,169.77,169.74,169.66\left(7 \mathrm{C}, \mathrm{CH}_{3} \mathrm{COO}\right)$, $97.33\left(\mathrm{C}-1^{\prime}\right), 81.47$ (C-1), 71.04, 69.56, 69.54 (C-5), 69.41, 68.88, 68.59 (C-5'), 66.81 (C-6), 66.53, 66.05, 62.39 (C-6'), $25.08\left(\mathrm{SCH}_{2} \mathrm{CH}_{3}\right), 20.86,20.84,20.74,20.74,20.69,20.63,20.63\left(7 \mathrm{C}, \mathrm{CH}_{3} \mathrm{COO}\right), 14.57\left(\mathrm{SCH}_{2} \mathrm{CH}_{3}\right)$.

MS: $m / z=703.12\left[\mathrm{M}+\mathrm{Na}^{+}\right]$(calculated 703.19).

Propargyl (2', 3', ,4', 6' -tetra-O-acetyl- $\alpha$-D-mannopyranosyl)-(1 $\rightarrow 6)$-2,3,4-tri-O-acetyl- $\alpha$-Dmannopyranoside (14)

2,3,4,6-Tetra-O-acetyl- $\alpha$-D-mannopyranosyl trichloracetimidate (9) $(1.1 \mathrm{~g}, 2.233 \mathrm{mmol}, 2 \mathrm{eq}$.$) and$ propargyl 2,3,4-tri-O-acetyl- $\alpha$-D-mannopyranoside (5a) $(0.384 \mathrm{~g}, 1.115 \mathrm{mmol}, 1$ eq. $)$ were dissolved in dry dichloromethane $(35 \mathrm{~mL})$ in presence of $4 \AA$ molecular sieves and cooled to $0{ }^{\circ} \mathrm{C}$ under argon atmosphere. $\mathrm{BF}_{3} \mathrm{OEt}_{2}\left(137.6 \mu \mathrm{L}, 1.115 \mathrm{mmol}, 1 \mathrm{eq}\right.$.) was added, and the mixture was stirred at $0{ }^{\circ} \mathrm{C}$ for $4 \mathrm{~h}$. The reaction was quenched with triethylamine ( $155 \mu \mathrm{L}, 1.115 \mathrm{mmol}, 1$ eq.), stirred for $5 \mathrm{~min}$, filtered over Celite, 
and concentrated in vacuo. The reaction mixture was monitored by TLC (dichloromethane/acetone 9:1, $\mathrm{Rf}=0.61)$. Column chromatography $\left(\mathrm{SiO}_{2}\right.$, dichloromethane/acetone 9:1) gave the desired product as a white solid $(0.676 \mathrm{~g}, 90 \%)$.

${ }^{1} \mathrm{H}-\mathrm{NMR}\left(400 \mathrm{MHz}, \mathrm{CDCl}_{3}\right): \delta 5.38-5.25$ (m, 6H, H-4' $\left., \mathrm{H}-3^{\prime}, \mathrm{H}-2^{\prime}, \mathrm{H}-4, \mathrm{H}-3, \mathrm{H}-2\right), 5.03$ (d, $1 \mathrm{H}$, $J=1.8 \mathrm{~Hz}, \mathrm{H}-1), 4.87\left(\mathrm{~d}, 1 \mathrm{H}, J=1.7 \mathrm{~Hz}, \mathrm{H}-1^{\prime}\right), 4.32\left(\mathrm{~d}, 2 \mathrm{H}, J=2.4 \mathrm{~Hz}, \mathrm{OCH}_{2} \mathrm{C} \equiv \mathrm{CH}\right), 4.28(\mathrm{dd}, 1 \mathrm{H}, J=5.3$ $\mathrm{Hz}, 12.4 \mathrm{~Hz}, \mathrm{H}-6_{\mathrm{a}}^{\prime}$ ), 4.15 (dd, 1H, J = 2.4 Hz, $\left.12.2 \mathrm{~Hz}, \mathrm{H}-6_{\mathrm{b}}^{\prime}\right), 4.12-3.98$ (m, 2H, H-5' , H-5), 3.80 (dd, 1H, $\left.J=5.7 \mathrm{~Hz}, 11 \mathrm{~Hz}, \mathrm{H}-6_{\mathrm{b}}\right), 3.60\left(\mathrm{dd}, 1 \mathrm{H}, J=2.6 \mathrm{~Hz}, 11 \mathrm{~Hz}, \mathrm{H}-6_{\mathrm{a}}\right), 2.53(\mathrm{t}, 1 \mathrm{H}, J=2.4 \mathrm{~Hz}, \mathrm{C} \equiv \mathrm{CH}), 2.18,2.17$, $2.12,2.07,2.06,2.01,2.00\left(7 \mathrm{~s}, 21 \mathrm{H}, \mathrm{COCH}_{3}\right)$.

${ }^{13} \mathrm{C}-\mathrm{NMR}\left(600 \mathrm{MHz}, \mathrm{CDCl}_{3}\right): \delta 170.59,170.04,169.94,169.83,169.79,169.74,169.70\left(7 \mathrm{C}, \mathrm{CH}_{3} \mathrm{COO}\right)$, $97.51\left(\mathrm{C}-1^{\prime}\right), 96.03(\mathrm{C}-1), 78.05\left(\mathrm{OCH}_{2} \mathrm{C} \equiv \mathrm{CH}\right), 75.60\left(\mathrm{OCH}_{2} \mathrm{C} \equiv \mathrm{CH}\right), 69.85(\mathrm{C}-5), 69.35,69.29,69.01,68.98$, 68.65 (C-5'), 66.64 (C-6), 66.44, 65.97, 62.42 (C-6'), $54.95\left(\mathrm{OCH}_{2} \mathrm{C} \equiv \mathrm{CH}\right), 20.84,20.75,20.72,20.70,20.70$, 20.64, $20.62\left(7 \mathrm{C}, \mathrm{CH}_{3} \mathrm{COO}\right)$.

HRMS: $m / z=697.1943\left[\mathrm{M}+\mathrm{Na}^{+}\right]$(calculated 697.1950).

Allyl (2', 3', , $4^{\prime}, 6^{\prime}$-tetra-O-acetyl- $\alpha$-D-mannopyranosyl)-(1 $\left.\rightarrow 6\right)$-2,3,4-tri-O-acetyl- $\alpha$-D-mannopyranoside (15)

2,3,4,6-Tetra-O-acetyl- $\alpha$-D-mannopyranosyl trichloracetimidate (9) (226.4 mg, $0.460 \mathrm{mmol}, 1$ eq.) and allyl 2,3,4-tri-O-acetyl- $\alpha$-D-mannopyranoside (6a) (159 mg, $0.460 \mathrm{mmol}, 1$ eq.) were dissolved in dry dichloromethane $(5 \mathrm{~mL})$ in presence of activated molecular sieves and cooled to $0{ }^{\circ} \mathrm{C}$ under nitrogen atmosphere. $\mathrm{BF}_{3} \mathrm{OEt}_{2}\left(56 \mu \mathrm{L}, 0.460 \mathrm{mmol}, 1 \mathrm{eq}\right.$.) was added, and the mixture was stirred at $0{ }^{\circ} \mathrm{C}$ for $2 \mathrm{~h}$. The reaction was quenched with triethylamine $(64.2 \mu \mathrm{L}, 0.460 \mathrm{mmol}, 1$ eq.), stirred for $5 \mathrm{~min}$, filtered, and concentrated in vacuo. The reaction mixture was monitored by TLC (dichloromethane/acetone 9:1, $\mathrm{Rf}=0.74)$ and purified by flash chromatography $\left(\mathrm{SiO}_{2}\right.$, toluene/methanol 9:1). The desired product was obtained as white solid (156 $\mathrm{mg}, 50 \%)$.

${ }^{1} \mathrm{H}-\mathrm{NMR}\left(400 \mathrm{MHz} \mathrm{CDCl}_{3}\right): \delta$ 5.98-5.88 (m, 1H, $\left.\mathrm{CH}_{2} \mathrm{CH}=\mathrm{CH}_{2}\right), 5.41-5.23(\mathrm{~m}, 8 \mathrm{H}, \mathrm{H}-2, \mathrm{H}-3, \mathrm{H}-4$ $\left.\mathrm{H}-2^{\prime}, \mathrm{H}-3^{\prime}, \mathrm{H}-4^{\prime}, \mathrm{CH}_{2} \mathrm{CH}=\mathrm{CH}_{2}\right), 4.88(\mathrm{~d}, 1 \mathrm{H}, \mathrm{J}=1.8 \mathrm{~Hz}, \mathrm{H}-1), 4.86\left(\mathrm{~d}, 1 \mathrm{H}, J=1.8 \mathrm{~Hz}, \mathrm{H}-1^{\prime}\right), 4.30-4.21$ $\left(\mathrm{m}, 2 \mathrm{H}, \mathrm{H}-6^{\prime}{ }_{\mathrm{a}}, \mathrm{CH}_{2} \mathrm{CH}=\mathrm{CH}_{2}\right), 4.16(\mathrm{dd}, 1 \mathrm{H}, \mathrm{J}=12.2,2.4 \mathrm{~Hz}, \mathrm{H}-5), 4.14-3.97\left(\mathrm{~m}, 3 \mathrm{H}, \mathrm{H}-5^{\prime}, \mathrm{H}^{-} 6^{\prime}{ }_{\mathrm{b}}\right.$, $\left.\mathrm{CH}_{2} \mathrm{CH}=\mathrm{CH}_{2}\right), 3.80\left(\mathrm{dd}, 1 \mathrm{H}, J=10.9,6.0 \mathrm{~Hz}, \mathrm{H}-6_{\mathrm{a}}\right), 3.58\left(\mathrm{dd}, 1 \mathrm{H}, J=10.9,2.5 \mathrm{~Hz}, \mathrm{H}-6_{\mathrm{b}}\right), 2.17,2.17,2.13$, $2.07,2.06,2.01,2.00\left(7 \mathrm{~s}, 21 \mathrm{H}, \mathrm{CH}_{3} \mathrm{COO}\right)$.

${ }^{13} \mathrm{C}-\mathrm{NMR}\left(400 \mathrm{MHz}, \mathrm{CDCl}_{3}\right): \delta 170.63,170.18,169.99,169.89,169.89,169.77,169.69(7 \mathrm{C}, \mathrm{COO})$, $133.04\left(\mathrm{CH}_{2} \mathrm{CH}=\mathrm{CH}_{2}\right), 118.42\left(\mathrm{CH}_{2} \mathrm{CH}=\mathrm{CH}_{2}\right), 97.43(\mathrm{C}-1), 96.26\left(\mathrm{C}-1^{\prime}\right), 69.61,69.42,69.36,69.17,68.95$, 68.64, $68.55\left(\mathrm{CH}_{2} \mathrm{CH}=\mathrm{CH}_{2}\right), 66.63,66.63,66.04(\mathrm{C}-6), 62.42\left(\mathrm{C}-6^{\prime}\right), 20.87,20.82,20.74,20.74,20.70,20.70$, 20.64 (7C, $\left.\mathrm{CH}_{3} \mathrm{COO}\right)$.

MS: $m / z=699.25\left[\mathrm{M}+\mathrm{Na}^{+}\right]$(calculated 699.21).

Cyanomethyl (2', $3^{\prime}, 4^{\prime}, 6^{\prime}$-tetra-O-acetyl- $\alpha$-D-mannopyranosyl)-(1 $\left.\rightarrow 6\right)$-2-acetamido-3,4-di-O-acetyl-2deoxy-1-thio- $\beta$-D-glucopyranoside (16)

Cyanomethyl (2', $3^{\prime}, 4^{\prime}, 6^{\prime}$-tetra-O-acetyl- $\alpha$-D-mannopyranosyl)-(1 $\left.\rightarrow 6\right)$-2-acetamido-3,4-di-O-acetyl2-deoxy-1-thio- $\beta$-D-glucopyranoside (16) was synthesized as reported by Zheng C. et al. [15]. Briefly, 2,3,4,6-tetra-O-acetyl- $\alpha$-D-mannopyranosyl trichloracetimidate (9) (235 mg, $0.478 \mathrm{mmol}, 2$ eq.) and cyanomethyl 2-acetamido-3,4-di-O-acetyl-2-deoxy-1-thio- $\beta$-D-glucopyranoside (8a) (86 mg, $0.239 \mathrm{mmol}$, 1 eq.) were dissolved in dry dichloromethane $(25 \mathrm{~mL})$ in presence of activated molecular sieves and cooled to $0{ }^{\circ} \mathrm{C}$ under nitrogen atmosphere. $\mathrm{BF}_{3} \mathrm{OEt}_{2}(59 \mu \mathrm{L}, 0.478 \mathrm{mmol}, 2 \mathrm{eq}$.) was added, and the mixture was stirred at room temperature for $2.5 \mathrm{~h}$. The reaction was quenched with triethylamine $(67 \mu \mathrm{L}, 0.478 \mathrm{mmol}$, 2 eq.), stirred for $5 \mathrm{~min}$, filtered, and concentrated in vacuo. The reaction mixture was monitored by TLC (ethyl acetate/diethyl ether 3:2, $\mathrm{Rf}=0.39)$ and purified by flash chromatography $\left(\mathrm{SiO}_{2}\right.$, ethyl acetate/ diethyl ether 3:2). The desired product was obtained as a as a colorless oil (122 $\mathrm{mg}, 74 \%)$.

${ }^{1} \mathrm{H}-\mathrm{NMR}\left(400 \mathrm{MHz}, \mathrm{CDCl}_{3}\right): \delta 5.95(\mathrm{~d}, 1 \mathrm{H}, J=9.2 \mathrm{~Hz}, \mathrm{NH}), 5.39-5.17\left(\mathrm{~m}, 4 \mathrm{H}, \mathrm{H}-4{ }^{\prime}, \mathrm{H}-3{ }^{\prime}, \mathrm{H}-2^{\prime}\right.$, H-3), 5.05 (t, 1H, J = 9.3 Hz, H-4), $4.86\left(\mathrm{~s}, 1 \mathrm{H}, \mathrm{H}_{-1}^{\prime}\right), 4.80$ (d, 1H, J = $\left.10.3 \mathrm{~Hz}, \mathrm{H}-1\right), 4.29$ (dd, 1H, J = 12.4, $5.1 \mathrm{~Hz}, \mathrm{H}-6^{\prime}{ }_{\mathrm{a}}$ ), 4.25-4.09 (m, 2H, H-2, H-6 ${ }_{\mathrm{b}}$ ), 4.02 (m, broad, 1H, H-5'), 3.83-3.76 (m, 2H, H-6 $\left.{ }_{\mathrm{a}}, \mathrm{H}-5\right)$, 
$3.73(\mathrm{~d}, 1 \mathrm{H}, J=17.1 \mathrm{~Hz}, \mathrm{CHCN}) 3.63-3.54\left(\mathrm{~m}, 1 \mathrm{H}, \mathrm{H}-6_{\mathrm{b}}\right), 3.38(\mathrm{~d}, 1 \mathrm{H}, J=17.1 \mathrm{~Hz}, \mathrm{CHCN}), 2.17,2.13$, $2.08,2.07,2.06,2.01,1.99\left(21 \mathrm{H}, \mathrm{CH}_{3} \mathrm{COO}\right)$.

${ }^{13} \mathrm{C}-\mathrm{NMR}\left(400 \mathrm{MHz}, \mathrm{CDCl}_{3}\right): \delta 171.22,170.68,170.53,170.09,169.90,169.72,169.42\left(7 \mathrm{C}, \mathrm{CH}_{3} \mathrm{COO}\right)$, $116.40\left(\mathrm{SCH}_{2} \mathrm{CN}\right), 97.36\left(\mathrm{C}-1^{\prime}\right), 83.30(\mathrm{C}-1), 76.85(\mathrm{C}-5), 73.23(\mathrm{C}-3), 69.38\left(\mathrm{C}-3^{\prime}\right), 68.96\left(\mathrm{C}-5^{\prime}\right), 68.86\left(\mathrm{C}-2^{\prime}\right)$, 68.83 (C-4), 66.70 (C-6), 66.03 (C-4'), 62.41 (C-6'), 52.76 (C-2), $23.14\left(\mathrm{CH}_{3}, \mathrm{NHAc}\right), 20.87,20.79,20.72$, $20.67,20.65,20.61\left(6 \mathrm{C}, \mathrm{CH}_{3} \mathrm{COO}\right), 14.62\left(\mathrm{SCH}_{2} \mathrm{CN}\right)$.

MS: $m / z=713.10\left[\mathrm{M}+\mathrm{Na}^{+}\right]$(calculated 713.18).

Cyanomethyl $\left(2^{\prime}, 3^{\prime}, 4^{\prime}, 6^{\prime}\right.$-Tetra-O-acetyl- $\alpha$-D-mannopyranosyl)-(1 $\left.\rightarrow 2\right)-3,4,6$-tri-O-acetyl-1-thio- $\alpha$-Dmannopyranoside (17)

2,3,4,6-Tetra-O-acetyl- $\alpha$-D-mannopyranosyl trichloracetimidate (9) $(202 \mathrm{mg}, 0.41 \mathrm{mmol}, 1$ eq.) and cyanomethyl 3,4,6-tri-O-acetyl-1-thio- $\alpha$-D-mannopyranoside $(\mathbf{2 b})(148 \mathrm{mg}, 0.41 \mathrm{mmol}, 1$ eq.) were dissolved in dry dichloromethane $(5 \mathrm{~mL})$ in presence of activated molecular sieves and cooled to $-63{ }^{\circ} \mathrm{C}$ under argon atmosphere. $\mathrm{BF}_{3} \mathrm{OEt}_{2}(50.6 \mu \mathrm{L}, 0.41 \mathrm{mmol}, 1$ eq.) was added, and the mixture was stirred for $30 \mathrm{~min}$. After, the solution was allowed to warm to room temperature and stirred for $1 \mathrm{~h}$. The reaction was quenched with triethylamine ( $57 \mu \mathrm{L}, 0.41 \mathrm{mmol}, 1$ eq.), stirred for $5 \mathrm{~min}$, filtered over Celite, and concentrated in vacuo. The reaction mixture was monitored by TLC (dichloromethane/acetone 9:1, $\mathrm{Rf}=0.42)$. Column chromatography $\left(\mathrm{SiO}_{2}\right.$, dichloromethane/acetone 9:1) gave the desired product as white solid (149 mg, 52.6\%).

${ }^{1} \mathrm{H}-\mathrm{NMR}\left(400 \mathrm{MHz}, \mathrm{CDCl}_{3}\right): \delta 5.63(\mathrm{~d}, 1 \mathrm{H}, J=1.9 \mathrm{~Hz}, \mathrm{H}-1), 5.45-5.39\left(\mathrm{~m}, 2 \mathrm{H}, \mathrm{H}-4, \mathrm{H}-3^{\prime}\right), 5.31$ $\left(\mathrm{t}, 1 \mathrm{H}, J=9.9 \mathrm{~Hz}, \mathrm{H}-4^{\prime}\right), 5.27\left(\mathrm{dd}, 1 \mathrm{H}, J=3.4,1.9, \mathrm{H}-2^{\prime}\right), 5.16(\mathrm{dd}, 1 \mathrm{H}, J=9.6,3.3, \mathrm{H}-3), 4.96(\mathrm{~d}, 1 \mathrm{H}$,

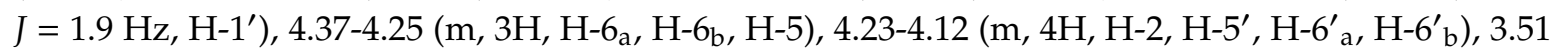
$\left(\mathrm{d}, 1 \mathrm{H}, J=17.1 \mathrm{~Hz}, \mathrm{SCH}_{2} \mathrm{CN}\right), 3.40\left(\mathrm{~d}, 1 \mathrm{H}, J=17.1 \mathrm{~Hz}, \mathrm{SCH}_{2} \mathrm{CN}\right), 2.17,2.17,2.13,2.12,2.08,2.07,2.04$ $\left(7 \mathrm{~s}, 21 \mathrm{H}, \mathrm{CH}_{3} \mathrm{COO}\right)$.

${ }^{13} \mathrm{C}-\mathrm{NMR}\left(400 \mathrm{MHz}, \mathrm{CDCl}_{3}\right): \delta 170.74,170.65,170.32,169.87,169.74,169.51,169.25\left(7 \mathrm{C}, \mathrm{CH}_{3} \mathrm{COO}\right)$, $115.75\left(\mathrm{SCH}_{2} \mathrm{CN}\right), 99.15\left(\mathrm{C}-1^{\prime}\right), 83.33$ (C-1), 76.70 (C-2), 70.35 (C-3), $70.04(\mathrm{C}-5), 69.60,69.60\left(\mathrm{C}-2^{\prime}, \mathrm{C}-5^{\prime}\right)$, 68.30, 66.48, 65.95 (C-4, C-4', C-3'), 62.60 (C-6'), 61.77 (C-6), 20.84, 20.76, 20.68, 20.64, 20.64, 20.62, 20.62 (7C, $\left.\mathrm{CH}_{3} \mathrm{COO}\right), 15.91\left(\mathrm{SCH}_{2} \mathrm{CN}\right)$.

MS: $m / z=714.21\left[\mathrm{M}+\mathrm{Na}^{+}\right]$(calculated 714.65).

Propargyl (2', $3^{\prime}, 4^{\prime}, 6^{\prime}$-tetra-O-acetyl- $\alpha$-D-mannopyranosyl)-(1 $\left.\rightarrow 2\right)$-3,4,6-tri-O-acetyl- $\alpha$-D-mannopyranoside (18)

2,3,4,6-Tetra-O-acetyl- $\alpha$-D-mannopyranosyl trichloracetimidate (9) $(212 \mathrm{mg}, 0.43 \mathrm{mmol}, 1$ eq.) and propargyl 3,4,6-tri-O-acetyl- $\alpha$-D-mannopyranoside $(5 \mathbf{b})(150 \mathrm{mg}, 0.43 \mathrm{mmol}, 1$ eq. $)$ were dissolved in dry dichloromethane $(8 \mathrm{~mL})$ in presence of activated molecular sieves. The solution was cooled to $-50{ }^{\circ} \mathrm{C}$ under argon atmosphere. $\mathrm{BF}_{3} \mathrm{OEt}_{2}(49.7 \mu \mathrm{L}, 0.43 \mathrm{mmol}, 1$ eq. $)$ was added to the flask, and the solution was allowed to warm to room temperature and stirred for $18 \mathrm{~h}$. The reaction was quenched with triethylamine (155 $\mu \mathrm{L}, 1.115 \mathrm{mmol}, 1$ eq.), stirred for $5 \mathrm{~min}$, filtered over Celite, and concentrated in vacuo. The reaction mixture was monitored by TLC (dichloromethane/acetone 9:1, $\mathrm{Rf}=0.70$ ). Column chromatography $\left(\mathrm{SiO}_{2}\right.$, dichloromethane/acetone 9:1) gave the desired product as a white solid (232 $\mathrm{mg}, 80 \%)$.

${ }^{1} \mathrm{H}-\mathrm{NMR}\left(400 \mathrm{MHz}, \mathrm{CDCl}_{3}\right): \delta 5.45-5.27\left(\mathrm{~m}, 5 \mathrm{H}, \mathrm{H}-3^{\prime}, \mathrm{H}-4, \mathrm{H}-4^{\prime}, \mathrm{H}-3, \mathrm{H}-2^{\prime}\right), 5.18(\mathrm{~d}, 1 \mathrm{H}, J=2.0 \mathrm{~Hz}$, $\mathrm{H}-1), 4.95\left(\mathrm{~d}, 1 \mathrm{H}, J=2.0 \mathrm{~Hz}, \mathrm{H}-1^{\prime}\right), 4.29\left(\mathrm{~d}, 2 \mathrm{H}, J=2.4 \mathrm{~Hz}, \mathrm{OCH}_{2} \mathrm{C} \equiv \mathrm{CH}\right), 4.28-4.22\left(\mathrm{~m}, 2 \mathrm{H}, \mathrm{H}-6_{\mathrm{a}}, \mathrm{H}-6_{\mathrm{b}},\right)$, 4.20-4.12 (m, 3H, H-5' $\left.{ }^{\prime} \mathrm{H}_{-}{ }^{\prime}{ }_{\mathrm{a}}, \mathrm{H}-6^{\prime}{ }_{\mathrm{b}}\right), 4.07(\mathrm{dd}, 1 \mathrm{H}, J=1.2,2.0 \mathrm{~Hz} \mathrm{H}-2), 4.00-3.95(\mathrm{~m}, 1 \mathrm{H}, \mathrm{H}-5), 2.51$ (t, $1 \mathrm{H}$, $J=2.4 \mathrm{~Hz}, \mathrm{C} \equiv \mathrm{CH}), 2.17,2.16,2.11,2.10,2.06,2.05,2.03\left(7 \mathrm{~s}, 21 \mathrm{H}, \mathrm{CH}_{3} \mathrm{COO}\right)$.

${ }^{13} \mathrm{C}-\mathrm{NMR}\left(101 \mathrm{MHz}, \mathrm{CDCl}_{3}\right): \delta 170.86,170.54,170.33,169.83,169.70,169.44,169.33\left(7 \mathrm{C}, \mathrm{CH}_{3} \mathrm{COO}\right)$, $99.20\left(\mathrm{C}-1^{\prime}\right), 96.92(\mathrm{C}-1), 78.11\left(\mathrm{OCH}_{2} \mathrm{C} \equiv \mathrm{CH}\right), 76.75(\mathrm{C}-2), 75.54\left(\mathrm{OCH}_{2} \mathrm{C} \equiv \mathrm{CH}\right), 70.06\left(\mathrm{C}-2^{\prime}\right), 69.75$ (C-3), $69.24\left(\mathrm{C}-5^{\prime}\right), 69.09$ (C-5), $68.41\left(\mathrm{C}-3^{\prime}\right), 66.31\left(\mathrm{C}-4^{\prime}\right), 66.09(\mathrm{C}-4), 62.35\left(\mathrm{C}-6_{\mathrm{a}}\right), 62.03\left(\mathrm{C}-6^{\prime}\right), 55.00$ $\left(\mathrm{OCH}_{2} \mathrm{C} \equiv \mathrm{CH}\right), 20.90,20.87,20.74,20.71,20.67,20.67,20.65$ (7C, $\left.\mathrm{CH}_{3} \mathrm{COO}\right)$.

HRMS: $m / z=697.1950\left[\mathrm{M}+\mathrm{Na}^{+}\right]$(calculated 697.1950). 


\subsection{Enzymatic Deprotection of Disaccharides 10-18}

The deacetylated disaccharides were produced following a general procedure of hydrolysis.

The substrates (10 mM final concentration; $5 \mathrm{mM}$ for 12$)$ were dissolved in acetonitrile $(20 \%-30 \% v / v$ depending on substrate solubility) under magnetic stirring, and then phosphate buffer (50 mM, $\mathrm{pH}$ 4.0-5.8) was added slowly. The reaction was started through the addition of immobilized CRL and/or AXE, previously conditioned with reaction buffer. The reactions were performed at $25^{\circ} \mathrm{C}$ under mechanical stirring; the $\mathrm{pH}$ of the solution was maintained constant by automatic titration. Reaction course was monitored by TLC.

After complete consumption of the starting substrate or before an excessive formation of undesired products, the reactions were stopped by enzymatic derivative filtration on Büchner funnel. Acetonitrile was evaporated under reduced pressure, and the solution was brined and extracted with ethyl acetate. The organic layers were dried over anhydrous $\mathrm{Na}_{2} \mathrm{SO}_{4}$, filtered, and concentrated in vacuo. The mixture obtained was purified by flash chromatography.

$2^{\prime}, 3^{\prime}, 4^{\prime}, 6^{\prime}$-Tetra-O-acetyl- $\alpha$-D-mannopyranosyl-(1 $\left.\rightarrow 6\right)-2,3,4$-tri-O-acetyl- $\alpha$-D-mannopyranose (10a)

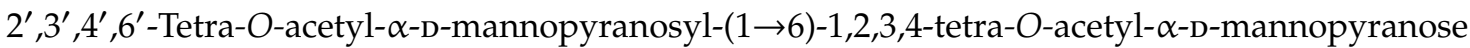
(10) was hydrolyzed to the corresponding $2^{\prime}, 3^{\prime}, 4^{\prime}, 6^{\prime}$-tetra-O-acetyl- $\alpha$-D-mannopyranosyl-(1 $\left.\rightarrow 6\right)-2,3,4-$ tri-O-acetyl- $\alpha$-D-mannopyranose (10a) following the general procedure for enzymatic hydrolysis: substrate $(10 \mathrm{mg}, 10 \mathrm{mM})$ was solubilized in $1.7 \mathrm{~mL}$ of phosphate buffer $50 \mathrm{mM} \mathrm{pH} 4.8$ and $30 \% v / v$ of acetonitrile. The reaction was started through addition of AXE-GLX-AG (52 UI). The reaction mixture was monitored by TLC (dichloromethane/methanol 9:1, $\mathrm{Rf}=0.76$ ). The product was identified by comparing the reaction mixture with standard material produced in-house [53].

Cyanomethyl $\quad\left(2^{\prime}, 3^{\prime}, 4^{\prime}, 6^{\prime}\right.$-tetra-O-acetyl- $\alpha$-D-mannopyranosyl)-(1 $\left.\rightarrow 6\right)-3,4$-di-O-acetyl-1-thio- $\alpha$-Dmannopyranoside (11a)

Cyanomethyl $\quad\left(2^{\prime}, 3^{\prime}, 4^{\prime}, 6^{\prime}\right.$-tetra-O-acetyl- $\alpha$-D-mannopyranosyl)-2,3,4-tri-O-acetyl-1-thio- $\alpha$-Dmannopyranoside (11) was hydrolyzed to the corresponding cyanomethyl $\left(2^{\prime}, 3^{\prime}, 4^{\prime}, 6^{\prime}\right.$-tetra-O-acetyl$\alpha$-D-mannopyranosyl)-(1 $\rightarrow 6)-3,4$-di-O-acetyl-1-thio- $\alpha$-D-mannopyranoside (11a) following the general procedure for enzymatic hydrolysis: substrate $(69 \mathrm{mg}, 10 \mathrm{mM})$ was solubilized in $8.5 \mathrm{~mL}$ of phosphate buffer $50 \mathrm{mM} \mathrm{pH} 5.3$ and $30 \% v / v$ of acetonitrile. The reaction was started through addition of AXE-GLX-AG (560 UI). The reaction mixture was monitored by TLC (dichloromethane/acetone 8:2, $\mathrm{Rf}=0.53)$. Column chromatography $\left(\mathrm{SiO}_{2}\right.$, dichloromethane/acetone 8:2) gave the desired product as a white sticky solid (15 mg, 23\%).

${ }^{1} \mathrm{H}-\mathrm{NMR}\left(400 \mathrm{MHz}, \mathrm{CDCl}_{3}\right): \delta 5.58(\mathrm{~d}, 1 \mathrm{H}, J=1.4 \mathrm{~Hz}, \mathrm{H}-1), 5.36(\mathrm{t}, 1 \mathrm{H}, J=9.9 \mathrm{~Hz}, \mathrm{H}-4), 5.33-5.29$ $\left(\mathrm{m}, 2 \mathrm{H}, \mathrm{H}-4^{\prime}, \mathrm{H}^{\prime} 3^{\prime}\right), 5.24\left(\mathrm{t}, 1 \mathrm{H}, \mathrm{J}=2.2 \mathrm{~Hz}, \mathrm{H}-2^{\prime}\right), 5.18(\mathrm{dd}, 1 \mathrm{H}, J=9.9,3.2 \mathrm{~Hz}, \mathrm{H}-3), 4.90(\mathrm{~d}, 1 \mathrm{H}, J=1.7 \mathrm{~Hz}$, H-1' $), 4.33-4.24$ (m, 2H, H-6 ${ }^{\prime}$ a $\left.\mathrm{H}-5\right), 4.22$ (dd, 1H, J = 3.3, $\left.1.4 \mathrm{~Hz}, \mathrm{H}-2\right), 4.17$ (dd, $1 \mathrm{H}, J=12.2,2.6 \mathrm{~Hz}$, H- $\left.6^{\prime}{ }_{\mathrm{b}}\right), 4.13-4.07\left(\mathrm{~m}, 1 \mathrm{H}, \mathrm{H}-5^{\prime}\right), 3.87$ (dd, 1H, J = 10.8, 7.0 Hz, H-6a ), 3.60 (dd, 1H, J = 10.7, 2.3 Hz, H- $6_{\mathrm{b}}$ ), $3.56\left(\mathrm{~d}, 1 \mathrm{H}, J=17.3 \mathrm{~Hz}, \mathrm{SCH}_{2} \mathrm{CN}\right), 3.38\left(\mathrm{~d}, 1 \mathrm{H}, J=17.3 \mathrm{~Hz}, \mathrm{SCH}_{2} \mathrm{CN}\right), 2.18,2.14,2.12,2.08,2.08,2.02$ (5s, $\left.18 \mathrm{H}, \mathrm{CH}_{3} \mathrm{COO}\right)$.

${ }^{13} \mathrm{C}-\mathrm{NMR}\left(400 \mathrm{MHz}, \mathrm{CDCl}_{3}\right): \delta 170.83,170.22,170.08,169.44,169.81,169.80(6 \mathrm{C}, \mathrm{COO}), 115.88$ $\left(\mathrm{SCH}_{2} \mathrm{CN}\right), 97.00\left(\mathrm{C}-1^{\prime}\right), 83.33(\mathrm{C}-1), 71.69(\mathrm{C}-3), 70.37(\mathrm{C}-5), 69.53\left(\mathrm{C}-2, \mathrm{C}-2^{\prime}\right), 68.92\left(\mathrm{C}-5^{\prime}\right), 68.72$, 66.49 (C-4), 65.96 (C-6), 65.88, 62.53 (C-6') , 20.88, 20.80, 20.77, 20.71, 20.67, 20.67 (6C, $\left.\mathrm{CH}_{3} \mathrm{COO}\right), 15.21$ $\left(\mathrm{SCH}_{2} \mathrm{CN}\right)$.

MS: $m / z=672.09\left[\mathrm{M}+\mathrm{Na}^{+}\right]$(calculated 672.16).

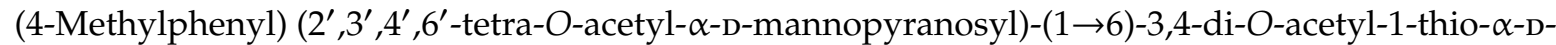
mannopyranoside (12a)

(4-Methylphenyl) (2', $3^{\prime}, 4^{\prime}, 6^{\prime}$-tetra-O-acetyl- $\alpha$-D-mannopyranosyl-(1 $\left.\rightarrow 6\right)-2,3,4$-tri-O-acetyl-1-thio$\alpha$-D-mannopyranoside (12) was hydrolyzed to the corresponding (4-methylphenyl) $\left(2^{\prime}, 3^{\prime}, 4^{\prime}, 6^{\prime}\right.$-tetra- $O$ acetyl- $\alpha$-D-mannopyranosyl)-( $1 \rightarrow 6)$-3,4-di-O-acetyl-1-thio- $\alpha$-D-mannopyranoside(12a) following the 
general procedure for enzymatic hydrolysis: substrate $(75 \mathrm{mg}, 10 \mathrm{mM})$ was solubilized in $20.37 \mathrm{~mL}$ of phosphate buffer $50 \mathrm{mM} \mathrm{pH} 5.4$ and 30\% v/v of acetonitrile. The reaction was started through addition of AXE-GLX-AG (420 UI). The reaction mixture was monitored by TLC (dichloromethane/acetone 9:1, $\mathrm{Rf}=0.22)$. Column chromatography $\left(\mathrm{SiO}_{2}\right.$, dichloromethane/acetone 9:1) gave the desired product as a white sticky solid (17 mg, 24\%).

${ }^{1} \mathrm{H}-\mathrm{NMR}\left(400 \mathrm{MHz}, \mathrm{CDCl}_{3}\right): \delta 7.39(\mathrm{~d}, 2 \mathrm{H} \mathrm{J}=8.0 \mathrm{~Hz}, \mathrm{Ar}), 7.17(\mathrm{~d}, 2 \mathrm{H}, J=8.0 \mathrm{~Hz}, \mathrm{Ar}), 5.46$ $(\mathrm{d}, J=1.9 \mathrm{~Hz}, 1 \mathrm{H}, \mathrm{H}-1), 5.42$ (d, 1H, J = 9.9 Hz, H-4) 5.36-5.24 (m, 4H, H-2' , H-3' , H-4' , H-3), 4.92 (d, 1H, $\left.J=1.6 \mathrm{~Hz}, \mathrm{H}-1^{\prime}\right), 4.50(\mathrm{ddd}, 1 \mathrm{H}, J=10.0,5.0,2.4 \mathrm{~Hz}, \mathrm{H}-5), 4.35-4.31$ (m, 1H, H-2) $4.28(\mathrm{dd}, 1 \mathrm{H}, J=12.3$, $5.1 \mathrm{~Hz}, \mathrm{H}-6_{\mathrm{a}}^{\prime}$ ), 4.09 (dd, 1H, $J=12.3,2.5 \mathrm{~Hz}, \mathrm{H}_{-}{ }^{\prime}{ }_{\mathrm{b}}$ ), 4.03 (ddt, $\left.1 \mathrm{H}, J=7.5,5.1,2.2 \mathrm{~Hz}, 1 \mathrm{H}, \mathrm{H}-5^{\prime}\right), 3.85$ $\left(\mathrm{dd}, 1 \mathrm{H}, J=11.4,5.0 \mathrm{~Hz}, \mathrm{H}-6_{\mathrm{a}}\right), 3.62\left(\mathrm{dd}, 1 \mathrm{H}, J=11.4,2.5 \mathrm{~Hz}, \mathrm{H}-6_{\mathrm{b}}\right), 2.34\left(\mathrm{~s}, 3 \mathrm{H}, \mathrm{CH}_{3}-\mathrm{Ar}\right), 2.16,2.12$, $2.11,2.09,2.07,2.02\left(6 \mathrm{~s}, 18 \mathrm{H}, \mathrm{COCH}_{3}\right)$.

${ }^{13} \mathrm{C}-\mathrm{NMR}\left(400 \mathrm{MHz}, \mathrm{CDCl}_{3}\right): \delta 170.72,170.17,169.98,169.76,169.76,169.74\left(6 \mathrm{C}, \mathrm{CH}_{3} \mathrm{COO}\right), 138.07$, 132.21, 130.06, 129.39 (Ar), 97.81 (C-1'), 88.06 (C-1), 71.86 (C-3), 70.59 (C-2), 70.28 (C-5), 69.62, 69.00, $68.61\left(\mathrm{C}-5^{\prime}\right), 66.84(\mathrm{C}-6), 66.69$ (C-4), 66.05, 62.35 (C-6') , 21.13( $\left.\mathrm{CH}_{3}-\mathrm{Ar}\right), 20.89,20.89,20.75,20.73,20.73$, $20.67\left(6 \mathrm{C}, \mathrm{CH}_{3} \mathrm{COO}\right)$.

MS: $m / z=723.24\left[\mathrm{M}+\mathrm{Na}^{+}\right]$(calculated 723.19).

Ethyl (2', $3^{\prime}, 4^{\prime}, 6^{\prime}$-tetra-O-acetyl- $\alpha$-D-mannopyranosyl)-(1 $\left.\rightarrow 6\right)-3,4$-di-O-acetyl-1-thio- $\alpha$-D-mannopyranoside (13a)

Ethyl $\quad\left(2^{\prime}, 3^{\prime}, 4^{\prime}, 6^{\prime}\right.$-tetra-O-acetyl- $\alpha$-D-mannopyranosyl)-(1 $\left.\rightarrow 6\right)-2,3,4$-tri-O-acetyl-1-thio- $\alpha$-Dmannopyranoside (13) was hydrolyzed to the corresponding ethyl $\left(2^{\prime}, 3^{\prime}, 4^{\prime}, 6^{\prime}\right.$-tetra-O-acetyl- $\alpha$-D-

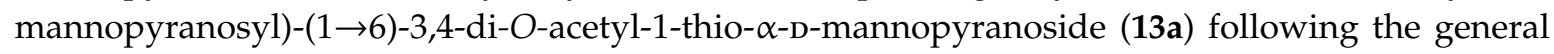
procedure for enzymatic hydrolysis: substrate $(28 \mathrm{mg}, 10 \mathrm{mM})$ was solubilized in $4.39 \mathrm{~mL}$ of phosphate buffer $50 \mathrm{mM} \mathrm{pH} 4.8$ and $30 \% v / v$ of acetonitrile. The reaction was started through addition of AXE-GLX-AG (160 UI). The reaction mixture was monitored by TLC (dichloromethane/acetone 8:2, $\mathrm{Rf}=0.62)$. Column chromatography $\left(\mathrm{SiO}_{2}\right.$, dichloromethane/acetone 9:1) gave the desired product as a white solid (10 $\mathrm{mg}, 38 \%)$.

${ }^{1} \mathrm{H}-\mathrm{NMR}\left(400 \mathrm{MHz}, \mathrm{CDCl}_{3}\right): \delta 5.35$ (m, 1H, H-1) 5.33-5.22 (m, 5H, H-4, H-4' $\left.{ }^{\prime} \mathrm{H}-3^{\prime}, \mathrm{H}-2^{\prime}, \mathrm{H}-3,\right), 4.90$ $\left(\mathrm{d}, 1 \mathrm{H}, J=1.8 \mathrm{~Hz}, \mathrm{H}-1^{\prime}\right), 4.40(\mathrm{ddd}, 1 \mathrm{H}, J=9.3,6.5,2.2 \mathrm{~Hz}, \mathrm{H}-5), 4.26-4.14$ (m, 3H, H-6 $\left.{ }_{\mathrm{a}}, \mathrm{H}-6^{\prime}{ }_{\mathrm{b}}, \mathrm{H}-2\right)$ $4.11\left(\mathrm{ddd}, 1 \mathrm{H}, J=9.7,5.4,2.4 \mathrm{~Hz}, 1 \mathrm{H}, \mathrm{H}-5^{\prime}\right), 3.83(\mathrm{dd}, 1 \mathrm{H}, J=10.9,6.6 \mathrm{~Hz}, \mathrm{H}-6 \mathrm{a}), 3.57(\mathrm{dd}, 1 \mathrm{H}, J=10.9$, $\left.2.2 \mathrm{~Hz}, \mathrm{H}-6_{\mathrm{b}}\right), 2.75-2.59\left(\mathrm{~m}, 2 \mathrm{H}, \mathrm{SCH}_{2} \mathrm{CH}_{3}\right), 2.17,2.13,2.10,2.07,2.06,2.01\left(6 \mathrm{~s}, 18 \mathrm{H}, \mathrm{COCH}_{3}\right), 1.35(\mathrm{t}, 3 \mathrm{H}$, $\left.J=7.4, \mathrm{SCH}_{2} \mathrm{CH}_{3}\right)$.

${ }^{13} \mathrm{C}-\mathrm{NMR}\left(400 \mathrm{MHz}, \mathrm{CDCl}_{3}\right): \delta 170.82,170.17,169.94,169.81,169.81,169.81\left(6 \mathrm{C}, \mathrm{CH}_{3} \mathrm{COO}\right), 97.39$ $\left(\mathrm{C}-1^{\prime}\right), 83.21$ (C-1), 72.03, 70.64 (C-2), 69.61, 69.43 (C-5), 68.84, 68.53 (C-5'), 66.96, 66.47 (C-6), 66.15, 62.47 $\left(\mathrm{C}-6^{\prime}\right), 24.79\left(\mathrm{SCH}_{2} \mathrm{CH}_{3}\right), 20.90,20.87,20.78,20.74,20.70,20.67\left(6 \mathrm{C}, \mathrm{CH}_{3} \mathrm{COO}\right), 14.56\left(\mathrm{SCH}_{2} \mathrm{CH}_{3}\right)$.

MS: $m / z=661.22\left[\mathrm{M}+\mathrm{Na}^{+}\right]$(calculated 661.18).

Propargyl (2' $3^{\prime}, 4^{\prime}$, 6' -tetra-O-acetyl- $\alpha$-D-mannopyranosyl)-(1 $\left.\rightarrow 6\right)$-3,4-di-O-acetyl- $\alpha$-D-mannopyranoside (14a)

Propargyl $\quad\left(2^{\prime}, 3^{\prime}, 4^{\prime}, 6^{\prime}\right.$-tetra-O-acetyl- $\alpha$-D-mannopyranosyl)-(1 $\left.\rightarrow 6\right)-2,3,4$-tri-O-acetyl- $\alpha$-Dmannopyranoside (14) was hydrolyzed to the corresponding propargyl ( $2^{\prime}, 3^{\prime}, 4^{\prime}, 6^{\prime}$-tetra-O-acetyl- $\alpha$-Dmannopyranosyl)-(1 $\rightarrow 6)$-3,4-di-O-acetyl- $\alpha$-D-mannopyranoside $(\mathbf{1 4 a})$ following the general procedure for enzymatic hydrolysis: substrate $(81 \mathrm{mg}, 10 \mathrm{mM})$ was solubilized in $12 \mathrm{~mL}$ of phosphate buffer $50 \mathrm{mM} \mathrm{pH} 4.0$ and $30 \%$ v/v of acetonitrile. The reaction was started through addition of AXE-GLX-AG (404 UI). The reaction mixture was monitored by TLC (dichloromethane/acetone 8:2, $\mathrm{Rf}=0.41$ ) and purified by flash chromatography $\left(\mathrm{SiO}_{2}\right.$, dichloromethane/acetone 8:2). The desired product was obtained as a as a colorless oil (18.4 $\mathrm{mg}, 24 \%)$.

${ }^{1} \mathrm{H}-\mathrm{NMR}\left(400 \mathrm{MHz} \mathrm{CDCl}_{3}\right): \delta$ 5.38-5.25 (m, 5H, H-4' , H-3' $\left., \mathrm{H}-2^{\prime}, \mathrm{H}-4, \mathrm{H}-3\right), 5.10$ (d, 1H, J = 1.8 Hz, $\mathrm{H}-1), 4.92\left(\mathrm{~d}, 1 \mathrm{H}, \mathrm{J}=1.8 \mathrm{~Hz}, \mathrm{H}_{-1}^{\prime}\right), 4.31\left(\mathrm{~d}, 2 \mathrm{H}, \mathrm{J}=2.4 \mathrm{~Hz}, \mathrm{OCH}_{2} \mathrm{C} \equiv \mathrm{CH}\right), 4.26(\mathrm{dd}, 1 \mathrm{H}, J=5.5 \mathrm{~Hz}$, 12.4 Hz, H-6 ${ }_{\mathrm{a}}$ ), 4.19-4.10 (m, 2H, H-6 $\left.{ }_{\mathrm{b}}, \mathrm{H}-5^{\prime}\right), 4.09$ (dd, $\left.1 \mathrm{H}, J=2.9,1.9 \mathrm{~Hz}, \mathrm{H}-2\right), 4.00(\mathrm{ddd}, 1 \mathrm{H}, J=8.9$, 
6.0, $2.3 \mathrm{~Hz}, \mathrm{H}-5), 3.81\left(\mathrm{dd}, 1 \mathrm{H}, J=5.9 \mathrm{~Hz}, 11 \mathrm{~Hz}, \mathrm{H}-6_{\mathrm{b}}\right), 3.61$ (dd, $\left.1 \mathrm{H}, J=2.4 \mathrm{~Hz}, 11 \mathrm{~Hz}, \mathrm{H}-6_{\mathrm{a}}\right), 2.52$ $(\mathrm{t}, 1 \mathrm{H}, J=2.4 \mathrm{~Hz}, \mathrm{C} \equiv \mathrm{CH}), 2.17,2.13,2.11,2.07,2.06,2.01\left(6 \mathrm{~s}, 18 \mathrm{H}, \mathrm{COCH}_{3}\right)$.

${ }^{13} \mathrm{C}-\mathrm{NMR}\left(400 \mathrm{MHz}, \mathrm{CDCl}_{3}\right): \delta 170.78,170.16,169.88,169.88,169.88,169.81\left(6 \mathrm{C}, \mathrm{CH}_{3} \mathrm{COO}\right), 97.86$ (C-1), $96.35\left(\mathrm{C}-1^{\prime}\right), 78.32\left(\mathrm{OCH}_{2} \mathrm{C} \equiv \mathrm{CH}\right), 75.36\left(\mathrm{OCH}_{2} \mathrm{C} \equiv \mathrm{CH}\right), 71.48,69.83(\mathrm{H}-5), 69.58,69.18,68.99$ (C-2), 68.65 (C-5'), 66.67 (C-6), 66.60, 66.04, $62.46\left(\mathrm{C}-6^{\prime}\right), 54.82\left(\mathrm{OCH}_{2} \mathrm{C} \equiv \mathrm{CH}\right), 20.88,20.88,20.77,20.72,20.72$, $20.68\left(6 \mathrm{C}, \mathrm{CH}_{3} \mathrm{COO}\right)$.

MS: $m / z=655.58\left[\mathrm{M}+\mathrm{Na}^{+}\right]$(calculated 655.19).

Allyl (2', $3^{\prime}, 4^{\prime}, 6^{\prime}$-tetra-O-acetyl- $\alpha$-D-mannopyranosyl)-(1 $\left.\rightarrow 6\right)-3,4$-di-O-acetyl- $\alpha$-D-mannopyranoside (15a)

Allyl (2', $3^{\prime}, 4^{\prime}, 6^{\prime}$-tetra-O-acetyl- $\alpha$-D-mannopyranosyl)-(1 $\left.\rightarrow 6\right)$-2,3,4-tri-O-acetyl- $\alpha$-D-mannopyranoside (15) was hydrolyzed to the corresponding Allyl $\left(2^{\prime}, 3^{\prime}, 4^{\prime}, 6^{\prime}\right.$-tetra-O-acetyl- $\alpha$-D-mannopyranosyl)-(1 $\left.\rightarrow 6\right)-3,4-$ di-O-acetyl- $\alpha$-D-mannopyranoside (15a) following the general procedure for enzymatic hydrolysis: substrate $(103 \mathrm{mg}, 10 \mathrm{mM})$ was solubilized in $15.2 \mathrm{~mL}$ of phosphate buffer $50 \mathrm{mM} \mathrm{pH} 4.8$ and $30 \% \mathrm{v} / \mathrm{v}$ of acetonitrile. The reaction was started through addition of AXE-GLX-AG (504 UI). The reaction mixture was monitored by TLC (dichloromethane/acetone 8:2, $\mathrm{Rf}=0.33$ ). Column chromatography $\left(\mathrm{SiO}_{2}\right.$, dichloromethane/acetone 8:2,) gave the desired product as a white solid (50 $\mathrm{mg}, 52 \%$ ).

${ }^{1} \mathrm{H}-\mathrm{NMR}\left(400 \mathrm{MHz}, 45{ }^{\circ} \mathrm{C}, \mathrm{CDCl}_{3}\right): \delta 5.94$ (dddd, $\left.1 \mathrm{H}, J=17.2,10.4,6.2,5.3, \mathrm{CH}_{2} \mathrm{CH}=\mathrm{CH}_{2}\right)$, 5.39-5.24 (m, 7H, H-3, H-4, H-2' $\left., \mathrm{H}-3^{\prime}, \mathrm{H}^{-} 4^{\prime}, \mathrm{CH}_{2} \mathrm{CH}=\mathrm{CH}_{2}\right), 4.91(\mathrm{~d}, 1 \mathrm{H}, J=1.8 \mathrm{~Hz}, \mathrm{H}-1) 4.90(\mathrm{~d}, 1 \mathrm{H}$, $\left.J=1.8 \mathrm{~Hz}, \mathrm{H}-1^{\prime}\right), 4.28-4.21\left(\mathrm{~m}, 2 \mathrm{H}, \mathrm{H}-6^{\prime}{ }_{\mathrm{a}}, \mathrm{CH}_{2} \mathrm{CH}=\mathrm{CH}_{2}\right), 4.16\left(\mathrm{dd}, 1 \mathrm{H}, J=7.9,2.3 \mathrm{~Hz}, \mathrm{H}-6^{\prime}{ }_{\mathrm{b}}\right), 4.15-4.03$ $\left(\mathrm{m}, 3 \mathrm{H}, \mathrm{H}-2, \mathrm{H}-5^{\prime}, \mathrm{CH}_{2} \mathrm{CH}=\mathrm{CH}_{2}\right), 3.99(\mathrm{ddd}, 1 \mathrm{H}, J=9.9,6.1,2.4 \mathrm{~Hz}, \mathrm{H}-5), 3.80(\mathrm{dd}, 1 \mathrm{H}, J=10.9,6.2 \mathrm{~Hz}$, $\left.\mathrm{H}-6_{\mathrm{a}}\right), 3.58\left(\mathrm{dd}, 1 \mathrm{H}, J=10.9,2.3 \mathrm{~Hz}, \mathrm{H}-6_{\mathrm{b}}\right), 2.17,2.12,2.10,2.05,2.06,2.00\left(6 \mathrm{~s}, 18 \mathrm{H}, \mathrm{CH}_{3} \mathrm{COO}\right)$.

${ }^{13} \mathrm{C}-\mathrm{NMR}\left(400 \mathrm{MHz}, \mathrm{CDCl}_{3}\right): \delta 170.79,170.15,169.94,169.93,169.83,169.80\left(6 \mathrm{C}, \mathrm{CH}_{3} \mathrm{COO}\right), 133.25$ $\left(\mathrm{CH}_{2} \mathrm{CH}=\mathrm{CH}_{2}\right), 118.23\left(\mathrm{CH}_{2} \mathrm{CH}=\mathrm{CH}_{2}\right), 98.19(\mathrm{C}-1), 97.25\left(\mathrm{C}-1^{\prime}\right), 71.73,69.62,69.35,69.29,68.91,68.60$, 68.40, 66.76, 66.63, 66.11, 62.46 (11C, carbon ring), 20.90, 20.89, 20.77, 20.74. 20.70, 20.67 (6C, $\left.\mathrm{CH}_{3} \mathrm{COO}\right)$.

MS: $m / z=657.25\left[\mathrm{M}+\mathrm{Na}^{+}\right]$(calculated 657.20).

Cyanomethyl (3', $4^{\prime}, 6^{\prime}$-tri-O-acetyl- $\alpha$-D-mannopyranosyl)-(1 $\left.\rightarrow 6\right)$-2-acetamido-3,4-di-O-acetyl-2-deoxy1-thio- $\beta$-D-glucopyranoside (16a)

Cyanomethyl (2', $3^{\prime}, 4^{\prime}, 6^{\prime}$-tetra-O-acetyl- $\alpha$-D-mannopyranosyl)-(1 $\left.\rightarrow 6\right)$-2-acetamido-3,4-di-O-acetyl2-deoxy-1-thio- $\beta$-D-glucopyranoside (16) was hydrolyzed to the corresponding cyanomethyl ( $3^{\prime}, 4^{\prime}, 6^{\prime}$-tri-O-acetyl- $\alpha$-D-mannopyranosyl)-( $\left.1 \rightarrow 6\right)$-2-acetamido-3,4-di-O-acetyl-2-deoxy-1-thio- $\beta$-Dglucopyranoside (16a) following the general procedure for enzymatic hydrolysis: substrate $(80.5 \mathrm{mg}$, $10 \mathrm{mM}$ ) was solubilized in $11.6 \mathrm{~mL}$ of phosphate buffer $50 \mathrm{mM} \mathrm{pH} 4.5$ and $30 \% v / v$ of acetonitrile. The reaction was started through addition of AXE-GLX-AG (378 UI). The reaction mixture was monitored by TLC (dichloromethane/methanol 9:1, $\mathrm{Rf}=0.42$ ). Column chromatography $\left(\mathrm{SiO}_{2}\right.$, dichloromethane/acetone 8:2) gave the desired product as a white sticky solid (15.4 mg 20.5\%).

${ }^{1} \mathrm{H}-\mathrm{NMR}\left(400 \mathrm{MHz}, \mathrm{CDCl}_{3}\right): \delta 6.02(\mathrm{~d}, 1 \mathrm{H}, J=9.3 \mathrm{~Hz}, \mathrm{NH}), 5.39-5.07\left(\mathrm{~m}, 4 \mathrm{H}, \mathrm{H}-4{ }^{\prime}, \mathrm{H}-3^{\prime}, \mathrm{H}-3\right.$, $\mathrm{H}-4), 4.95\left(\mathrm{~d}, 1 \mathrm{H}, J=1.9 \mathrm{~Hz}, \mathrm{H}-\mathrm{1}^{\prime}\right), 4.75(\mathrm{~d}, 1 \mathrm{H}, J=10.4 \mathrm{~Hz}, \mathrm{H}-1), 4.29\left(\mathrm{dd}, 1 \mathrm{H}, J=12.3,4.9 \mathrm{~Hz}, \mathrm{H}-6^{\prime}{ }_{\mathrm{a}}\right)$, 4.25-4.10 (m, 3H, H-2, H-2' ${ }^{\prime} \mathrm{H}_{-}{ }^{\prime}{ }_{\mathrm{b}}$ ), 3.98 (ddd, $\left.1 \mathrm{H}, \mathrm{J}=9.9,4.9,2.4 \mathrm{~Hz}, \mathrm{H}-5^{\prime}\right)$ 3.85-3.64 (m, 4H, CHCN, $\left.\mathrm{H}-6_{\mathrm{a}}, \mathrm{H}-5, \mathrm{H}-6_{\mathrm{b}}\right), 3.34$ (d, 1H, J = 17.3 Hz, CHCN), 2.12, 2.10, 2.08, 2.07, 2.05, 1.99 (6s, 18H, CH $\mathrm{C}_{3} \mathrm{COO}$ ).

${ }^{13} \mathrm{C}-\mathrm{NMR}\left(400 \mathrm{MHz}, \mathrm{CDCl}_{3}\right): \delta 171.33,170.84,170.60,170.01,169.84,169.26\left(6 \mathrm{C}, \mathrm{CH}_{3} \mathrm{COO}\right), 116.53$ $\left(\mathrm{SCH}_{2} \mathrm{CN}\right), 99.63\left(\mathrm{C}-1^{\prime}\right), 83.36(\mathrm{C}-1), 77.18(\mathrm{C}-5), 73.46(\mathrm{C}-3), 71.35\left(\mathrm{C}-3^{\prime}\right), 68.92\left(\mathrm{C}-5^{\prime}\right), 68.78\left(\mathrm{C}-2^{\prime}\right), 68.67$ (C-4), 66.23 (C-6), 65.95 (C-4') 62.48 (C-6'), 52.57 (C-2), $23.11\left(\mathrm{CH}_{3}, \mathrm{NHAc}\right), 20.90,20.81,20.4,20.66$, $20.64\left(5 \mathrm{C}, \mathrm{CH}_{3} \mathrm{COO}\right), 14.50\left(\mathrm{SCH}_{2} \mathrm{CN}\right)$.

MS: $m / z=671.21\left[\mathrm{M}+\mathrm{Na}^{+}\right]$(calculated 671.17).

Cyanomethyl (2', , $3^{\prime}, 4^{\prime}, 6^{\prime}$-tetra-O-acetyl- $\alpha$-D-mannopyranosyl)-(1 $\left.\rightarrow 2\right)-3$,4-di-O-acetyl-1-thio- $\alpha$-Dmannopyranoside (17a)

Cyanomethyl $\left(2^{\prime}, 3^{\prime}, 4^{\prime}, 6^{\prime}\right.$-tetra-O-acetyl- $\alpha$-D-mannopyranosyl)-(1 $\left.\rightarrow 2\right)-3,4,6$-tri-O-acetyl-1-thio- $\alpha$-Dmannopyranoside (17) was hydrolyzed to the corresponding cyanomethyl $\left(2^{\prime}, 3^{\prime}, 4^{\prime}, 6^{\prime}\right.$-tetra-O-acetyl- 
$\alpha$-D-mannopyranosyl)-(1 $\rightarrow$ 2)-3,4-di-O-acetyl-1-thio- $\alpha$-D-mannopyranoside (17a) following the general procedure for enzymatic hydrolysis: substrate $(95 \mathrm{mg}, 10 \mathrm{mM})$ was solubilized in $13.10 \mathrm{~mL}$ of phosphate buffer $50 \mathrm{mM}$ pH 5.0 and $30 \%$ v/v of acetonitrile. The reaction was started through addition of AXE-GLX-AG (477 UI). The reaction mixture was monitored by TLC (dichloromethane/acetone 8:2, $\mathrm{Rf}=0.33)$. Column chromatography $\left(\mathrm{SiO}_{2}\right.$, dichloromethane/acetone 8:2) gave the desired product as a white solid (14.5 $\mathrm{mg}, 16 \%)$.

${ }^{1} \mathrm{H}-\mathrm{NMR}\left(400 \mathrm{MHz}, \mathrm{CDCl}_{3}\right): \delta 5.55(\mathrm{~d}, 1 \mathrm{H}, J=1.8 \mathrm{~Hz}, \mathrm{H}-1), 5.30\left(\mathrm{dd}, 1 \mathrm{H}, J=9.9,3.4 \mathrm{~Hz}, \mathrm{H}-3^{\prime}\right), 5.23$ $\left(\mathrm{t}, 2 \mathrm{H}, J=10.3 \mathrm{~Hz}, \mathrm{H}-4, \mathrm{H}-4^{\prime}\right), 5.18\left(\mathrm{dd}, 1 \mathrm{H}, J=3.4,1.9, \mathrm{H}-2^{\prime}\right), 5.11(\mathrm{dd}, 1 \mathrm{H}, J=9.7,3.3, \mathrm{H}-3), 4.86(\mathrm{~d}, 1 \mathrm{H}$, $\left.J=1.9 \mathrm{~Hz}, \mathrm{H}-1^{\prime}\right), 4.22\left(\mathrm{dd}, 1 \mathrm{H}, \mathrm{H}_{-} 6_{\mathrm{a}}{ }_{\mathrm{a}}\right), 4.16-4.09$ (m, 2H, H-2, H-5'), $4.06\left(\mathrm{dd}, 1 \mathrm{H}, J=11.9,2.9 \mathrm{~Hz}, \mathrm{H}-6^{\prime}{ }_{\mathrm{b}}\right)$, 4.00 (m, broad, 1H, J = 10.1, 4.5, $2.4 \mathrm{~Hz}, \mathrm{H}-5), 3.75-3.58\left(\mathrm{~m}, 2 \mathrm{H}, \mathrm{H}-6_{\mathrm{a}}, \mathrm{H}-6_{\mathrm{b}}\right), 3.41(\mathrm{~d}, 1 \mathrm{H}, J=17.2 \mathrm{~Hz}$, $\left.\mathrm{SCH}_{2} \mathrm{CN}\right), 3.31\left(\mathrm{~d}, 1 \mathrm{H}, \mathrm{J}=17.2 \mathrm{~Hz}, \mathrm{SCH}_{2} \mathrm{CN}\right), 2.08,2.05,2.04,2.02,2.01,1.95\left(6 \mathrm{~s}, 18 \mathrm{H}, \mathrm{CH}_{3} \mathrm{COO}\right)$.

${ }^{13} \mathrm{C}-\mathrm{NMR}\left(400 \mathrm{MHz}, \mathrm{CDCl}_{3}\right): \delta 170.88,170.36,170.34,169.91,169.91,169.67\left(6 \mathrm{C}, \mathrm{CH}_{3} \mathrm{COO}\right), 116.06$ $\left(\mathrm{SCH}_{2} \mathrm{CN}\right), 99.06\left(\mathrm{C}-1 '^{\prime}\right), 83.49$ (C-1), 76.86 (C-2), 72.27 (C-5), 70.27 (C-3), 69.51, $69.41\left(\mathrm{C}-5^{\prime}, \mathrm{C}-2^{\prime}\right), 68.46$ $\left(\mathrm{C}-3^{\prime}\right), 66.46,65.87\left(\mathrm{C}-4, \mathrm{C}-4^{\prime}\right), 62.83\left(\mathrm{C}-6^{\prime}\right), 61.07$ (C-6), 20.86, 20.84, 20.74, 20.71, 20.64, 20.61 (6C, $\left.\mathrm{CH}_{3} \mathrm{COO}\right), 15.02\left(\mathrm{SCH}_{2} \mathrm{CN}\right)$.

MS: $m / z=672.09\left[\mathrm{M}+\mathrm{Na}^{+}\right]$(calculated 672.16).

Propargyl (2' , 3' , 4' , 6' -tetra-O-acetyl- $\alpha$-D-mannopyranosyl)-(1 $\rightarrow 2)$-3,4-di-O-acetyl- $\alpha$-D-mannopyranoside (18a)

Propargyl $\quad\left(2^{\prime}, 3^{\prime}, 4^{\prime}, 6^{\prime}\right.$-tetra-O-acetyl- $\alpha$-D-mannopyranosyl)-(1 $\left.\rightarrow 2\right)-3,4,6$-tri-O-acetyl- $\alpha$-Dmannopyranoside (18) was hydrolyzed to the corresponding propargyl ( $2^{\prime}, 3^{\prime}, 4^{\prime}, 6^{\prime}$-tetra-O-acetyl- $\alpha$-Dmannopyranosyl)-(1 $\rightarrow 2)$-3,4-di-O-acetyl- $\alpha$-D-mannopyranoside $(\mathbf{1 8 a})$ following the general procedure for enzymatic hydrolysis: substrate $(38 \mathrm{mg}, 10 \mathrm{mM})$ was solubilized in $5.6 \mathrm{~mL}$ of phosphate buffer $50 \mathrm{mM}$ pH 5.8 and $30 \% v / v$ of acetonitrile. The reaction was started through addition of AXE-GLX-AG (102 UI). The reaction mixture was monitored by TLC (dichloromethane/acetone 8:2). Column chromatography $\left(\mathrm{SiO}_{2}\right.$, dichloromethane/acetone 9:1, $\left.\mathrm{Rf}=0.17\right)$ gave the desired product as a white solid $(7 \mathrm{mg}, 20 \%)$.

${ }^{1} \mathrm{H}-\mathrm{NMR}\left(400 \mathrm{MHz}, \mathrm{CDCl}_{3}\right): \delta 5.40\left(\mathrm{dd}, 1 \mathrm{H}, J=10.0,3.3 \mathrm{~Hz}, \mathrm{H}-3{ }^{\prime}\right), 5.37-5.26\left(\mathrm{~m}, 4 \mathrm{H}, \mathrm{H}-3, \mathrm{H}-4, \mathrm{H}-4^{\prime}\right.$, $\left.\mathrm{H}-2^{\prime}\right), 5.19(\mathrm{~d}, 1 \mathrm{H}, \mathrm{J}=2.0 \mathrm{~Hz}, \mathrm{H}-1), 4.95\left(\mathrm{~d}, 1 \mathrm{H}, \mathrm{J}=1.9 \mathrm{~Hz}, \mathrm{H}-1^{\prime}\right), 4.29\left(\mathrm{~d}, 2 \mathrm{H}, \mathrm{J}=2.4 \mathrm{~Hz}, \mathrm{OCH} \mathrm{C}^{\circ} \mathrm{CH}\right)$, 4.27-4.15 (m, 3H, H-5' , H-6 $^{\prime}{ }_{\mathrm{a}}, \mathrm{H}_{-} 6^{\prime}{ }_{\mathrm{b}}$ ) $), 4.10$ (dd, 1H, J = 3.2, $\left.2.0 \mathrm{~Hz}, \mathrm{H}-2\right), 3.78$ (ddd, 1H, J = 9.6, 4.4, 2.3 $\mathrm{Hz}, \mathrm{H}-5), 3-75-3.71$ (m, 2H, H-6a, $\left.\mathrm{H}-6_{\mathrm{b}}\right), 2.50\left(\mathrm{t}, 1 \mathrm{H}, \mathrm{J}=2.4 \mathrm{~Hz}, \mathrm{OCH}_{2} \mathrm{C} \equiv \mathrm{CH}\right), 2.17,2.13,2.11,2.09,2.08$, $2.03\left(6 \mathrm{~s}, 18 \mathrm{H}, \mathrm{CH}_{3} \mathrm{COO}\right)$.

${ }^{13} \mathrm{C}-\mathrm{NMR}\left(400 \mathrm{MHz}, \mathrm{CDCl}_{3}\right): \delta 170.91,170.39,170.35,169.92,169.89,169.63\left(6 \mathrm{C}, \mathrm{CH}_{3} \mathrm{COO}\right), 99.09$ $\left(\mathrm{C}-1^{\prime}\right), 96.86(\mathrm{C}-1), 78.20\left(\mathrm{OCH}_{2} \mathrm{C} \equiv \mathrm{CH}\right), 76.75(\mathrm{C}-2), 75.53\left(\mathrm{OCH}_{2} \mathrm{C} \equiv \mathrm{CH}\right), 71.33(\mathrm{C}-5), 69.96,69.64,69.13$ $\left(\mathrm{C}-5^{\prime}\right), 68.60\left(\mathrm{C}-3^{\prime}\right), 66.58,66.29,62.65\left(\mathrm{C}-6^{\prime}\right), 61.28(\mathrm{C}-6), 54.89\left(\mathrm{OCH}_{2} \mathrm{C} \equiv \mathrm{CH}\right), 20.87,20.83,20.73,20.73$, 20.73, 20.67, (6C, $\left.\mathrm{CH}_{3} \mathrm{COO}\right)$.

MS: $m / z=655.20\left[\mathrm{M}+\mathrm{Na}^{+}\right]$(calculated 655.19).

\section{Conclusions}

By using immobilized CRL or AXE, a library of acetylated mannose-based monosaccharide building blocks, selectively deprotected in position C6 or C2, was prepared. The proposed biocatalytic approach is versatile and simple since the building blocks can be obtained directly by enzymatic hydrolysis, starting from substrates with different reactive group/linker in anomeric position and using acetyl as the only protecting group in the other positions. Interestingly, AXE was also able to provide different acetylated disaccharides, selectively deprotected in position C2 or C6, when C2 position was involved in the glycosidic bond. All the products prepared are potentially useful in the synthesis of various oligosaccharides and their glycoconjugate derivatives.

Author Contributions: L.T.: investigation, methodology (disaccharides synthesis) and original draft preparation; M.S.R.: investigation, methodology (enzyme immobilization and enzymatic hydrolysis of acetylated mono- and disaccharides) and original draft preparation; S.M.: investigation, methodology (monosaccharides synthesis); T.R.: methodology/data curation (NMR); Y.Z. and M.T.: review and editing; T.B.: conceptualization, supervision of 
research activity planning and execution, review and editing. All authors have read and agreed to the published version of the manuscript.

Funding: This research received no external fundin. APC was sponsored by MDPI.

Acknowledgments: Authors would like specially to acknowledge Roberto Pavesi (ACS DOBFAR; Italy) that kindly provided soluble AXE.

Conflicts of Interest: The authors declare no conflict of interest.

\section{References}

1. Zhang, Y.; Lu, D.; Sollogoub, M.; Zhang, Y. Carbohydrate-carbohydrate interaction: From hypothesis to confirmation. In Carbohydrate Chemistry; Royal Society of Chemistry: Piccadilly, UK, 2016; Volume 41, pp. $238-254$.

2. Krasnova, L.; Wong, C.-H. Understanding the chemistry and biology of glycosylation with glycan synthesis. Annu. Rev. Biochem. 2016, 85, 599-630. [CrossRef]

3. Micoli, F.; Del Bino, L.; Alfini, R.; Carboni, F.; Romano, M.R.; Adamo, R. Glycoconjugate vaccines: Current approaches towards faster vaccine design. Expert Rev. Vaccines 2019, 18, 881-895. [CrossRef]

4. Weis, W.I.; Taylor, M.E.; Drickamer, K. The C-type lectin superfamily in the immune system. Immunol. Rev. 1998, 163, 19-34. [CrossRef] [PubMed]

5. McIntosh, J.D.; Brimble, M.A.; Brooks, A.E.S.; Dunbar, R.P.; Kowalczyk, R.; Tomabechi, Y.; Fairbanks, A.J. Convergent chemo-enzymatic synthesis of mannosylated glycopeptides; targeting of putative vaccine candidates to antigen presenting cells. Chem. Sci. 2015, 6, 4636-4642. [CrossRef] [PubMed]

6. Wang, L.X. Carbohydrate-based vaccines against HIV/AIDS. In Glycobiology and Drug Design; American Chemical Society: Washington, DC, USA, 2012; pp. 157-186.

7. Wang, L.-X. Synthetic carbohydrate antigens for HIV vaccine design. Curr. Opin. Chem. Biol. 2013, 17, 997-1005. [CrossRef] [PubMed]

8. Leelayuwapan, H.; Kangwanrangsan, N.; Chawengkirttikul, R.; Ponpuak, M.; Charlermroj, R.; Boonyarattanakalin, K.; Ruchirawat, S.; Boonyarattanakalin, S. Synthesis and immunological studies of the lipomannan backbone glycans found on the surface of Mycobacterium tuberculosis. J. Org. Chem. 2017, 82, 7190-7199. [CrossRef] [PubMed]

9. Krasnova, L.; Wong, C.-H. Oligosaccharide synthesis and translational innovation. J. Am. Chem. Soc. 2019, 141, 3735-3754. [CrossRef] [PubMed]

10. Panza, M.; Pistorio, S.G.; Stine, K.J.; Demchenko, A.V. Automated chemical oligosaccharide synthesis: Novel approach to traditional challenges. Chem. Rev. 2018, 118, 8105-8150. [CrossRef]

11. Wen, L.; Edmunds, G.; Gibbons, C.; Zhang, J.; Gadi, M.R.; Zhu, H.; Fang, J.; Liu, X.; Kong, Y.; Wang, P.G. Toward automated enzymatic synthesis of oligosaccharides. Chem. Rev. 2018, 118, 8151-8187. [CrossRef]

12. Calin, O.; Eller, S.; Seeberger, P.H. Automated polysaccharide synthesis: Assembly of a 30mer mannoside. Angew. Chem. Int. Ed. 2013, 52, 5862-5865. [CrossRef]

13. Unverzagt, C.; Eller, S.; Mezzato, S.; Schuberth, R. A double regio- and stereoselective glycosylation strategy for the synthesis of N-glycans. Chem. Eur. J. 2008, 14, 1304-1311. [CrossRef]

14. Flitsch, S.L. Glycosylation with a twist. Nature 2005, 437, 201-202. [CrossRef]

15. Zheng, C.; Bavaro, T.; Tengattini, S.; Mascherpa, A.G.; Sollogoub, M.; Zhang, Y.; Terreni, M. Chemoenzymatic synthesis of glycoconjugates mediated by regioselective enzymatic hydrolysis of acetylated 2-amino pyranose derivatives. Eur. J. Org. Chem. 2019, 3622-3631. [CrossRef]

16. Bavaro, T.; Pinto, A.; Dall'Oglio, F.; Hernaiz, M.J.; Morelli, C.F.; Zambelli, P.; De Micheli, C.; Conti, P.; Tamborini, L.; Terreni, M. Flow-based biocatalysis: Application to peracetylated arabinofuranosyl-1,5arabinofuranose synthesis. Process Biochem. 2018, 72, 112-118. [CrossRef]

17. Bavaro, T.; Filice, M.; Temporini, C.; Tengattini, S.; Serra, I.; Morelli, C.F.; Massolini, G.; Terreni, M. Chemoenzymatic synthesis of neoglycoproteins driven by the assessment of protein surface reactivity. RSC Adv. 2014, 4, 56455-56465. [CrossRef]

18. Filice, M.; Bavaro, T.; Fernandez-Lafuente, R.; Pregnolato, M.; Guisan, J.M.; Palomo, J.M.; Terreni, M. Chemo-biocatalytic regioselective one-pot synthesis of different deprotected monosaccharides. Catal. Today 2009, 140, 11-18. [CrossRef] 
19. Bavaro, T.; Torres-Salas, P.; Antonioli, N.; Morelli, C.F.; Speranza, G.; Terreni, M. Regioselective deacetylation of disaccharides via immobilized Aspergillus niger esterase(s)-catalyzed hydrolysis in aqueous and non-aqueous media. ChemCatChem 2013, 5, 2925-2931. [CrossRef]

20. Bavaro, T.; Torres-Salas, P.; Ubiali, D.; Terreni, M. Regioselective enzymatic hydrolysis of hexa-O-acetyl-lactal in a green non-aqueous medium. Rsc Adv. 2013, 3, 7355-7359. [CrossRef]

21. Bavaro, T.; Filice, M.; Bonomi, P.; Speranza, G.; Guisan, J.M.; Terreni, M. Regioselective deprotection of peracetylated disaccharides at the primary position catalyzed by immobilized acetyl xylan esterase from Bacillus pumilus. Eur. J. Org. Chem. 2011, 6181-6185. [CrossRef]

22. Filice, M.; Palomo, J.M.; Bonomi, P.; Bavaro, T.; Fernandez-Lafuente, R.; Guisan, J.M.; Terreni, M. Preparation of linear oligosaccharides by a simple monoprotective chemo-enzymatic approach. Tetrahedron 2008, 64, 9286-9292. [CrossRef]

23. Cacicedo, M.L.; Manzo, R.M.; Municoy, S.; Bonazza, H.L.; Islan, G.A.; Desimone, M.; Bellino, M.; Mammarella, E.J.; Castro, G.R. Immobilized enzymes and their applications. In Biomass, Biofuels, Biochemicals: Advances in Enzyme Technology; Elsevier: Amsterdam, The Netherlands, 2019; pp. 169-200.

24. Rodrigues, R.C.; Virgen-Ortiz, J.J.; dos Santos, J.C.S.; Berenguer-Murcia, Á.; Alcantara, A.R.; Barbosa, O.; Ortiz, C.; Fernandez-Lafuente, R. Immobilization of lipases on hydrophobic supports: Immobilization mechanism, advantages, problems, and solutions. Biotechnol. Adv. 2019, 37, 746-770. [CrossRef] [PubMed]

25. Bavaro, T.; Ubiali, D.; Brocca, S.; Rocchietti, S.; Nieto, I.; Pregnolato, M.; Lotti, M.; Terreni, M. Recombinant lipase from Candida rugosa for regioselective hydrolysis of peracetylated nucleosides. A comparison with commercial non-recombinant lipases. Biocatal. Biotransform. 2010, 28, 108-116. [CrossRef]

26. Fojan, P.; Jonson, P.H.; Petersen, M.T.N.; Petersen, S.B. What distinguishes an esterase from a lipase: A novel structural approach. Biochimie 2000, 82, 1033-1041. [CrossRef]

27. Chahinian, H.; Nini, L.; Boitard, E.; Dubès, J.-P.; Comeau, L.-C.; Sarda, L. Distinction between esterases and lipases: A kinetic study with vinyl esters and TAG. Lipids 2002, 37, 653-662. [CrossRef]

28. Montoro-García, S.; Gil-Ortiz, F.; García-Carmona, F.; Polo, L.M.; Rubio, V.; Sánchez-Ferrer, A. The crystal structure of the cephalosporin deacetylating enzyme acetyl xylan esterase bound to paraoxon explains the low sensitivity of this serin hydrolase to organophosphate inactivation. Biochem. J. 2011, 436, 321-330. [CrossRef]

29. Nakamura, A.M.; Nascimento, A.S.; Polikarpov, I. Structural diversity of carbohydrate esterases. Biotechnol. Res. Innov. 2017, 1, 35-51. [CrossRef]

30. Mateo, C.; Pessela, B.C.C.; Fuentes, M.; Torres, R.; Betancor, L.; Hidalgo, A.; Fernandez-Lorente, G.; Fernandez-Lafuente, R.; Guisan, J.M. Stabilization of multimeric enzymes via immobilization and further cross-linking with aldehyde-dextran. In Methods in Molecular Biology; Springer Nature: Berlin, Germany, 2020; pp. 175-187.

31. Lopez-Gallego, F.; Fernandez-Lorente, G.; Rocha-Martin, J.; Bolivar, J.M.; Mateo, C.; Guisan, J.M. Multi-point covalent immobilization of enzymes on glyoxyl agarose with minimal physico-chemical modification: Stabilization of industrial enzymes. In Immobilization of Enzymes and Cells; Springer Nature: Berlin, Germany, 2020; pp. 93-107.

32. Fernandez-Lafuente, R. Stabilization of multimeric enzymes: Strategies to prevent subunit dissociation. Enzym. Microb. Technol. 2009, 45, 405-418. [CrossRef]

33. Mateo, C.; Palomo, J.M.; Fuentes, M.; Betancor, L.; Grazu, V.; Lopez-Gallego, F.; Pessela, B.C.C.; Hidalgo, A.; Fernandez-Lorente, G.; Fernandez-Lafuente, R.; et al. Glyoxyl agarose: A fully inert and hydrophilic support for immobilization and high stabilization of proteins. Enzym. Microb. Technol. 2006, 39, 274-280. [CrossRef]

34. Li, Z.; Zheng, C.; Terreni, M.; Bavaro, T.; Sollogoub, M.; Zhang, Y. A concise synthesis of oligosaccharides derived from lipoarabinomannan (LAM) with glycosyl donors having a nonparticipating group at C2. Eur. J. Org. Chem. 2020, 2033-2044. [CrossRef]

35. Abualassal, Q.; Azzam, K.M.A.; Jilani, J.A. Regioselective deprotection of the monosaccharide-bearing thiocyanomethyl group at the anomeric position monitored by reversed-phase HPLC method. Biomed. Chromatogr. 2016, 30, 1416-1422. [CrossRef]

36. Torres-Salas, P.; Pedrali, A.; Bavaro, T.; Ambrosini, S.; Marrubini, G.; Pappalardo, V.M.; Massolini, G.; Terreni, M.; Ubiali, D. Preparation of PUFA concentrates as acylglycerols via enzymatic hydrolysis of hempseed oil (Cannabis sativa L.) in a homogeneous low-water medium: PUFA-based glyceride concentrates from hempseed oil. Eur. J. Lipid Sci. Technol. 2014, 116, 1496-1504. [CrossRef] 
37. Guisán, J.M. Aldehyde-agarose gels as activated supports for immobilization-stabilization of enzymes. Enzym. Microb. Technol. 1988, 10, 375-382. [CrossRef]

38. Bonomi, P.; Bavaro, T.; Serra, I.; Tagliani, A.; Terreni, M.; Ubiali, D. Modulation of the microenvironment surrounding the active site of penicillin $\mathrm{G}$ acylase immobilized on acrylic carriers improves the enzymatic synthesis of Cephalosporins. Molecules 2013, 18, 14349-14365. [CrossRef] [PubMed]

39. Bavaro, T.; Cattaneo, G.; Serra, I.; Benucci, I.; Pregnolato, M.; Terreni, M. Immobilization of neutral protease from Bacillus subtilis for regioselective hydrolysis of acetylated nucleosides: Application to Capecitabine synthesis. Molecules 2016, 21, 1621. [CrossRef] [PubMed]

40. Davis, B.G.; Seimour, L.W.; Fisher, K. Modified Virus. WO 2006/008513 A1, 26 January 2006.

41. Janssens, J.; Decruy, T.; Venken, K.; Seki, T.; Krols, S. Efficient divergent synthesis of new immunostimulant 4"-modified $\alpha$-galactosylceramide analogues. Acs Med. Chem. Lett. 2017, 8, 642-647. [CrossRef] [PubMed]

42. Sau, A.; Misra, A.K. Odorless eco-friendly synthesis of thio-and selenoglycosides in ionic liquid. Synlett 2011, 13, 1905-1911.

43. Calosso, M.; Tambutet, G.; Charpentier, D.; St-Pierre, G.; Vaillancourt, M.; Bencheqroun, M.; Gratton, J.-P.; Prev, M. Acyclic tethers mimicking subunits of polysaccharide ligands: Selectin antagonists. ACS Med. Chem. Lett. 2014, 5, 1054-1059. [CrossRef]

44. Mukhopadhyay, B.; Kartha, K.P.R.; Russell, D.A.; Field, R.A. Streamlined synthesis of per-O-acetylated sugars, glycosyl iodides, or thioglycosides from unprotected reducing sugars. J. Org. Chem. 2004, 69, 7758-7760. [CrossRef]

45. Schmid, S.; Mena-Osteritz, E.; Kopyshev, A.; Bäuerle, P. Self-assembling carbohydrate-functionalized oligothiophenes. Org. Lett. 2009, 11, 5098-5101. [CrossRef]

46. Balcerzak, A.K.; Ferreira, S.S.; Trant, J.F.; Ben, R.N. Structurally diverse disaccharide analogs of antifreeze glycoproteins and their ability to inhibit ice recrystallization. Bioorg. Med. Chem. Lett. 2012, 22, 1719-1721. [CrossRef]

47. Timmer, B.J.J.; Ramstrçm, O. Acid-assisted direct olefin metathesis of unprotected carbohydrates in water. Chem. Eur. J. 2019, 25, 14408-14413. [CrossRef] [PubMed]

48. Lee, C.-C.; Grandinetti, G.; McLendon, P.M.; Reineke, T.M. A polycation scaffold presenting tunable "click" sites: Conjugation to carbohydrate ligands and examination of hepatocyte-targeted pDNA delivery. Macromol. Biosci. 2010, 10, 585-598. [CrossRef] [PubMed]

49. Ekholm, F.S.; Poláková, M.; Pawłowicz, A.J.; Leino, R. Synthesis of divalent 2,2'-linked mannose derivatives by homodimerization. Synthesis 2009, 4, 567-576.

50. Horrobin, T.; Tran, C.H.; Crout, D. Esterase-catalysed regioselective 6-deacylation of hexopyranose per-acetates, acid-catalysed rearrangement to the 4-deprotected products and conversions of these into hexose 4- and 6-sulfates. J. Chem. Soc. Perkin Transform. 1998, 1, 1069-1080. [CrossRef]

51. Mari, S.; Sanchez-Medina, I.; Mereghetti, P.; Belvisi, L.; Jimenez-Barbero, J.; Bernardi, A. Synthesis and conformational analysis of an $\alpha$-D-mannopyranosyl-( $1 \rightarrow 2)-\alpha$-D-mannopyranosyl-(1 $\rightarrow 6)-\alpha$-D-mannopyranose mimic. Carbohydr. Res. 2007, 342, 1859-1868. [CrossRef]

52. Huang, S.; Yu, H.; Chen, X. Disaccharides as sialic acid aldolase substrates: Synthesis of disaccharides containing a sialic acid at the reducing end. Angew. Chem. Int. Ed. 2007, 46, 2249-2253. [CrossRef]

53. Tengattini, S.; Dominguez-Vega, E.; Temporini, C.; Bavaro, T.; Rinaldi, F.; Piubelli, L.; Pollegioni, L.; Massolini, G.; Somsen, G.W. Hydrophilic interaction liquid chromatography-mass spectrometry as a new tool for the characterization of intact semi-synthetic glycoproteins. Anal. Chim. Acta 2017, 981, 94-105. [CrossRef]

Sample Availability: Samples of the compounds are available from the authors.

Publisher's Note: MDPI stays neutral with regard to jurisdictional claims in published maps and institutional affiliations.

(C) 2020 by the authors. Licensee MDPI, Basel, Switzerland. This article is an open access article distributed under the terms and conditions of the Creative Commons Attribution (CC BY) license (http://creativecommons.org/licenses/by/4.0/). 